\title{
King Farouk and the Wafd's Relations with the United States After the 1952 Revolution (1952-1957)
}

\author{
Noha Osman Azmy
}

\author{
Associate Professor, Tourism Guidance Department, Faculty of Tourism and Hotels, Sadat City University
}

\begin{abstract}
:
King Farouk was deposed and forced to leave Egypt after the 1952 Revolution. Under the demand of the political purification, the Wafd party was dissolved and its leaders were imprisoned or kept under house arrest. The year 1955 marked the first contact between the Farouk and Wafd with the United States. The tense relation between US and Nasser that year gave hope for both to return to power with US support. The study depended on the US State Department documents to represent these connections and to show the American opinion with it. Unlike the previous studies, the study approved that the first contact of Farouk to the US was in 1955 not in 1956; in which he commented on the Middle East situation, the US's role in depositing him and described the new regime in Egypt. The Wafd also tried to gain the US support to return to power through two different approaches. One was ready to deal with Nasser but with parliamentary life depending on the Wafd's popularity; the second was to depose Nasser and replace him with Naguib with the return of the Wafd party to the political scene. The study concluded that these connections reflected the deep ideological difference between Farouk and Wafd and showed that the US's foreign policy was determined by its interest which was not anymore with either the Wafd or Farouk.
\end{abstract}

Keywords: King Farouk, Wafd, United States, 1952 Revolution, Egypt

\section{Introduction}

On the eve of the 23 July 1952, a group of young army officers seized power in Cairo with a minimum of bloodshed and resistance. The Free Officers tried to curtail the possibilities of British military interference and also to allay the fears of the British and other foreigners. At three o'clock in the morning, the Free Officers openly contacted the American Embassy. They sent their first message to the British embassy through David Evans, the American Air Force attaché. In the message, they informed the British that "the coup was purely an internal matter affecting Egyptian only and they would organize resistance to any British military interference".

The years from 1952 till 1956 were an important period in Egypt's history. It witnessed the collapse of the monarchy regime and the rise of the Republican one. The Suez Canal, joining the defense pact with the West and peace with Israel were the main targets of the United States in Egypt during that time. At the beginning, it thought that the Free Officers would be its way to achieving these goals, but since 1955, this vision has been changed. The tense relation between the US and President Gamal Abdel Nasser gave hope to the old regime leaders to gain the American support to depose Nasser and return to power. But soon after the Political success that Nasser achieved after the Tripartite Aggression in 1956 ended all of these dreams forever.

The military coup aimed to get rid of the corrupted political life that was presented in the King Farouk and the political parties, on the top of which was the Wafd. The United States' role in the 1952 coup has been the subject of many research studies in this period from a number of perspectives. Some discussed the relation between the US and the Free Officers even before 1952, others briefly talked about the US relation with the old monarchy regime that was mainly represented in the ex-King Farouk and the Wafd party.

Abdel Wahab S. Ahmed (1989) argued that The American embassy in Cairo was not only concerned for the safety of the coup d'état, but the American State Department did not hesitate to point out from the very beginning to the British that foreign intervention would be disastrous. Furthermore, the Americans officially informed the British Foreign Office that the United States would not intervene with British troops on behalf of King Farouk. Clearly, from the very outset of the coup, the US did everything possible to prevent the British from taking any active measures that might have led to the failure of the Free Officers' task. ${ }^{2}$ Concerning the Wafd and the US support, Ahmed claimed that The Americans began to be worried that they were going to face a difficult situation if the Wafd continued to exist. Getting rid of Farouk did not mean abolishing the ancient regime. The corrupt Wafd was still popular. Mustafa Nahas still enjoyed more advantages than Naguib and his colleagues. ${ }^{3}$

Alterman (2002) claimed that while the Embassy seemed not to have been behind the coup before it happened; it quickly swung behind the Free Officers in the immediate aftermath. The American Ambassador Caffery personally guaranteed the king's safe passage out of Egypt on July 26, 1952, and saw him off on the shore. The Head of the Free Officers, Mohammed 
Naguib wrote that at the time of the Revolution, Caffery was "one of the few foreign diplomats whom we believed we could trust."

Joel Jordon (1992) discussed that charges of direct U.S. complicity in the coup d'état couldn't be established with any certainty. More important, is the role the Americans - and the British — played in advising the officers, fostering their selfconfidence during a period in which they struggled for survival. ${ }^{5}$

About the US -King Farouk's relation, William Stadiem (1991), Barrie St. Clair McBride (1968) and Latifa M. Salim (2005) agreed that after long time of silence, at the height of the Suez Crisis, Farouk sent a confidential message to the British Prime Minister Anthony Eden, the American President Eisenhower and President of France, to try by all possible means to devise a peaceful solution of the problems which divided their government from the Egyptian people, who couldn't be held responsible for the mistake of their leaders. ${ }^{6}$

While all these studies are useful in one sense or another, the topic of the King Farouk and Wafd party's relation with the United States after the 1952 Revolution deserves a comprehensive holistic study which takes into consideration the full context of the local and global situation.

1955 witnessed a series of events that clouded the clear horizon in the relation between the US and the Free Officers that predicted a coming storm. While the Wafd leaders were in prisons or under house arrest, their representatives were trying to contact the US as Super power to depose the new regime.

This article argues that ex-King Farouk's first contact with the US was not in 1956 as most of the previous studies used to claim. His first contact was in 1955 to ensure the American failure to achieve its goals in the Middle East through the new military regime that he described them as Gangsters. the article also argued that Wafd party contacted the US after the 1952 Revolution through two main approaches, Cousin of Fuad Sirag al-Din, the Secretary of the Wafd party and Mahmoud Abu al-Fatah, the owner of al-Misri newspaper. Sirag al-Din tried to convince the US that the new regime failed to gain the same popularity of the Wafd, and that was the reason for the junta not to hold a parliament election in 1953. Abu al-Fath claimed that the new military regime was pro-communism and would be a threat to the US interest in Egypt.

The secret correspondence between the Wafd and the US from one side, and Ex-King Farouk and the US from other side represented that the conflict between Farouk and Wafd even after 1952 Revolution was on ideological principles. Farouk was well aware of the US role in his deposition but he contacted it for his beloved country in the critical times. The Wafd approached the US searching for returning their authority back from the new regime.

The US State Department documents will be the primary source material for this study that represented the secret correspondence and adds facts to Egypt's modern history concerning the old regime relation with the US after the 1952 Revolution. The American vision of the Wafd real interest, and their belief that both Farouk and the Wafd's role ended with their failure to achieve any of the expected goals. For the US, the new military regime, particularly Nasser deserved a good support internally and externally to realize its objectives.

\section{The United States and Farouk's Abdication}

During the course of the first day July 23, the heads of the army and air force were arrested, but later on during the week many other officers, high government officials and palace favorites were detained or prevented from leaving the country. Within twelve hours General Naguib presented to the King Farouk three demands: a) that Ali Maher should lead the government; b) that there should be immediate elections; C) that martial law should be abolished. The King acceded to these demands, and Ali Maher formed a new government consisting of most of his previous technician cabinet 9 February 1952.

On the morning of July 26, Ali Maher pasha was sent with an ultimatum to King Farouk forcing him to abdicate in favor of his baby, and leave the country by 6:00 p.m. Cairo time. Farouk signed the royal decree designating his son, Ahmed Fuad II, King of Egypt and the Sudan, appointed a Regency council, and sailed from Alexandria on the royal yacht Mahrousa, bound to Italy. ${ }^{7}$

On July 25, Caffery told Ali Maher, the Prime Minister nominated by the Free Officers, that the US regarded the events of the past few days as internal affairs, but at the same time, the US desired to make clear that it was following the situation with close intention and expect constitutional authorities would continue. ${ }^{8}$

Accordingly, Caffery sent a message to King Farouk from the state Department some twenty-four hours before his abdication. This message presented the American view "we do not wish to become involved in this situation". ${ }^{9}$ 
With this message the United States, to a certain extent, recognized the new regime. The Americans wanted to keep the King alive and showed their willingness to void unnecessary bloodshed before the operation. They understood that any harm to the king might precipitate British military intervention to protect him and resident foreign communities.

Farouk's intensions regarding keeping his throne were obvious. Anthony Eden, in his memoirs, wrote that from 8.00 am onwards, the King was frequently on the telephone to the US Ambassador. He repeated each time more clearly that only foreign intervention could save him and his dynasty. Caffery was firm with Farouk and did not lead him to indulge in false hopes. The ambassador pointed out to the King that there was no question of British intervention ....unless such intervention became necessary for the protection of foreign lives and property. Needless to state, Farouk lost all hope of any British military assistance. He failed to understand that it was primarily the American contribution behind his demise.

On July 24, King Farouk asked Caffery "if an American naval vessel could be supplied to get him out of Alexandria". On the following day, Farouk repeated his request to Caffery and the State Department. The Americans did not hesitate to point out to the King that "No American warship or plane could come to Egypt for this purpose". The Americans contributed to the collapse of the monarchy. Yet, despite the pressure of the Free Officers, Caffery did his best to ensure the King's personal safety. ${ }^{10}$

The army leader Naguib had reiterated that he has no intention of interfering in political matters these were the affairs of the new Prime Minister and that he was interested only in cleaning out corruption and graft in the armed forces and government and in forming a new, well equipped and well-trained army. ${ }^{11}$

The early American reports about the 1952 Revolution were keen to represent the influence of the Communism and the Muslim Brotherhood on the Free Officers. It mentioned that there was apparently little or no communist influence in the army, and there had been no evidence of communist elements at work in that latest upheaval. However, whenever there was change, the communists were certain to have a try at turning the change in their direction.

The Muslim Brotherhood had a certain amount of strength among the armed forces, and was entirely likely to have a strong influence in coup because the aims of the Muslim Brotherhood, like those professed by the coup group, were in the direction to a purge of all corruption, whether in material, moral, or religious matters. ${ }^{12}$

The Wafd had been sitting on the sideline for the last six months before the July revolution, waiting for an opportunity to regain the power wrested from it after the burning of Cairo on January 26. Nahas Pasha and Sirag al-Din pasha, the two most powerful members of the Wafd executives, returned to Cairo from Europe just after the revolution. They hailed Naguib as the savior of the Nation. ${ }^{13}$

\section{The Revolutionary Steps against Old Regime}

\section{a) The Political Parties Dissolution}

Three weeks after Farouk's abdication, the US was keen to review the Egyptian situation under the new regime. The American reports mentioned that the attitude of the Wafd towards the new movement, and vice versa, had from the beginning been of keen interest to all concerned. The political parties had not sufficient public following to be of much concern under present circumstances.

General Naguib early let it be known that the army was determined to see all aspects of Egyptian life purified of the corruption which had permeated the society under the aegis of the former regime.

Purification "Wafd-style", satisfied neither the junta, the Prime Minister, nor those Wafdists who looked to the army for support in their struggle to reform the party. Fu'ad Sirag al-Din argued that the burden should be upon the government either to name names or to spell out criteria. The senior Wafdists hastily formed a purge committee, which on August 4 summarily expelled fourteen members of the parliamentary organization, charged with disloyalty to the party. No one was fooled. "I am not pleased," Muhammad Nagib responded bluntly. "The corrupt elements are still present in the Wafd's leadership." ${ }^{14}$ The expulsions also provoked open rebellion within the Wafd. By late August a clear division had emerged inside the Wafd; this fracture between first- and second-generation Wafdists created an ad hoc alliance between the disaffected youth vanguard and those in line to succeed to party leadership. Second-generation leaders did not necessarily share the officers' ideas of who should run the Wafd, but they welcomed Wafdist allies of the Free Officers found themselves in an increasingly tenuous position.

His consultations with landowners on 26 August 1952, in conjunction with a statement made three days earlier by Mustafa Nahas Pasha, leader of the Wafd, that "The Wafd are the people and the people are the Wafd; the last word will be with the people," ${ }^{15}$ stirred the junta to counter-action. The regime announced on 9 September a party re-organization law which compelled the political parties to purify themselves by 7 October. By requiring the deposit of party funds and stipulating 
that the assets of any party not re-organized in accordance with the law would be donated to charity, the junta set its sights on the opulent Wafd. Nasser admitted that their main target was Fuad Sirag al-Din 'a brilliant and dangerous politician'.

The legal measures were followed with a bid to win wider popular support for the junta. In late September, Naguib undertook a three-day tour of the Nile Delta, the heartland of the Wafd, where he was met with genuinely enthusiastic crowds. In his brief speeches, Naguib stressed the political role of the army. "The army is the nation and every Egyptian a soldier," he repeated. "Patience, patience," he beseeched his audience. "It took God six days to create the world," he told them and asked for six months. ${ }^{16}$ The tour, described as "triumphal" in the American press, exhilarated the officers. This success gave the junta greater confidence in the challenging weeks that followed.

Naguib's response to the overtures of the Wafd leaders Mustafa al-Nahas and Fuad Sirag al-Din was to call for a clear declaration of party aims. That resulted in the publications of a flood of lengthy party programs dealing in greater or lesser detail with proposed solutions for the political, economic, and social problems of the country. When the commander in Chief followed up with a demand for self-political parties, the Wafd hastily announced the dismissal of three ex-ministers and a number of former Deputies. ${ }^{17}$ The Wafd's 'purification' submission in early October boldly retained Nahas as honorary party leader, despite pressure for him to step down because of corruption allegations. The Officers had given themselves a self-imposed deadline of 8 November to accept or reject all the submissions. ${ }^{18}$

On 5 November, the junta refused to accept Nahas even as the 'honorary' leader of a purified Wafd party. The Wafd responded by challenging the legality of the party law in the State Council. The threat of the Wafd remained, however, especially given its past record for exploiting nationalist feelings and economic misery to gain power.

By late November, the junta's star appeared to be in decline. The officers had made no positive steps toward negotiations with the British. Price controls imposed on basic foodstuffs had produced serious shortages. Retailers refused to purchase goods with fixed prices, and peasants hesitated to plant fruits and vegetables from which they could reap no profit. The Wafd, rallying around Nahhas, seemed poised to make a bid for power. Rumors of dissension within the junta promoted an image of weakness. A series of challenges in the courts and on university campuses fueled the officers' disenchantment. In addition to the Wafd case pending before the State Council, Sirag al-Din, and other politicians interned since September initiated a lawsuit against the government protesting their detention without their having been formally charged. Rumors spread of a drawing together of old antagonists in prison. In response, the authorities placed the offenders in solitary confinement. More disconcerting to the regime, unrest erupted at Cairo University, where student elections pitted traditional rivals, a communist-Wafdist coalition, and the Muslim Brothers, against each other. With the junta openly supporting the Brothers, the elections became a tacit referendum on the regime. When the coalition won, the government arrested some one hundred students, dissolved the student union, and closed the university. ${ }^{19}$

On December 22 the government announced the creation of a special "Treason Court" (Mahkamat al-Ghadr) to try cases of corruption and abuse of power under the old regime. The first set of indictments was handed down on January 1. Six former ministers and seven former parliamentary deputies, all Wafdists, were charged. Fu'ad Sirag al-Din headed the list. Despite the regime's aggressive stance, Wafdist leaders failed to read the writing on the wall. They continued to view the junta as a transient phase and never questioned their own ultimate return to power. This blind self-assuredness along with the party disunity that plagued the Wafd throughout the early years of the revolution precluded a forceful, united stand until it was too late. Mustafa al-Nahas appeared to have been genuinely deceived by Naguib's amiability and his own mistaken assessment of the Wafd's relative strength vis-a-vis the junta. In his meeting with Naguib in mid-December, the Wafdist chief warned the Prime Minister against banning the party. Shortly thereafter, he let it be known he would not cooperate with a constitutional committee appointed by the government. ${ }^{20}$

In late December 1952 or early January, 1953 Wafdist insiders contacted the British embassy, hoping to ingratiate themselves with the British. Their sights were totally blurred. Officials in both the British and U.S. embassies knew that the time for old hicks had passed, that the officers had no intention of handing power back to the Wafd.

On 10 January 1953, the legal case against the party law came back before the State Council. Amidst chaotic scenes, a senior Wafdist told the court that only the people could dissolve the Wafd. The court was adjourned on the I3th with a decision promised in February. But before a verdict could be delivered a planned counter-coup was foiled, and in the following days, the court case and constitutional deliberations fell by the wayside. ${ }^{21}$ On 16 January 1953, they confiscated the party funds, dissolved the parties, and announced that there would be a three-year transitional period preceding the restoration of democratic life. This date, in fact, marks the point at which the junta acknowledged that they must work on their own for some time to come. On 23 January, the six- months' anniversary of the coup d'état, General Naguib announced the formation of the Liberation Rally as a popular movement enshrining the doctrine of 'unity, discipline, and work' which had become the slogan of the new regime. ${ }^{22}$ 
The US saw that proved to be on all counts incredibly poor tactics on the part of the Wafd. Not only was no one fooled by the phony purge, but the very action had been publicly taken as an admission of guilt by the Wafd. It had the consequences of breeding serious internal dissension within the party with the result that the Wafd's position had been so weakened that the military has largely lost their early fear of the Wafd's power. ${ }^{23}$

\section{b) The Land Reform}

The Prime Minister, Ali Maher, on another hand, had from the beginning favored a policy of discrediting and, if possible, destroying the Wafd. In his political statement to the nation on August 10, Ali Maher went to the extent of openly attacking the existing political parties en bloc and posing the choice of complete reform and reorganization or disintegration and disappearance. The military clique evidently felt that that was going too far, and, spurred by dissatisfaction with the government's rate of progress on agrarian reform, they issued a communiqué immediately following the Prime Minister's broadcast which constituted the first open indication of any friction between the army and the government. ${ }^{24}$

As the great bulk of the Egyptian population was engaged in farming, Social reform was virtually synonymous with agrarian reform. It was, therefore, not surprising that the first reform proposal to emanate from the military was a proposal to limit individual and family agricultural landholdings.

As early as August 5, press reports appeared indicating that the military social planners were thinking in terms of a maximum ownership of 500 feddans per persons. While Ali Maher ${ }^{25}$ appeared to have been from the first in general agreement on the need for agrarian reform, particularly as a deterrent to communism, differences quickly developed between the government and leaders of the military movement over questions of approach and timing.

Those with real power in the Wafd opposed the idea. The officers invited Sirag al-Din to discuss the matter on August 14. Participants described the meeting, which lasted four to six hours, as one of complete candor in which Sirag al-Din argued against an imposed limit on landholding. He proposed instead, much like Ali Mahir, a tax scheme that would place a greater burden on large holders. On September 6, three days before the bill became law, Sirag al-Din announced that the Wafd agreed with it in principle. The party, however, had a number of reservations that, he said, would be elucidated at a later date. This position did not satisfy the junta. Zakariya Muhyi al-Din told the British Military Attaché in mid-August that "the army and the government were urgently trying to amass evidence against Sirag al-Din but they did not wish to move against him until they had a cast iron case. ...". ${ }^{26}$

The US saw that the military clique, sincerely solicitous of the downtrodden Egyptian fellah and desiring to have a concrete achievement to their credit in the field of agrarian reform, have been pushing hard for quick action to limit land ownership. 27

The Prime Minister, preferring a last drastic approach to rural reform, at first, dragged his feet to the point of precipitating a serious divergence between the government and the military. ${ }^{28}$ His argument was that smaller holdings would result in lower productivity and economic chaos would ensue. But he also knew that radical land distribution was the junta's method for undercutting the political influence of Egypt's pasha elite and establishing its own links with the peasants (fellaheen).

On 3 September, Secretary of State Dean Acheson, on the advice of Caffery, issued a statement praising recent developments in Egypt. British officials were furious, partly for not being consulted beforehand but mainly because they feared that the junta would interpret the move as a blank cheque to adopt radical policies. on the night of the 5th, sixty leading politicians and palace favorites were arrested, followed the next day by the dismissal of Maher.

An agricultural reform law was promulgated on the 7th and Naguib was appointed prime minister on the 8th. Maher's dismissal prompted a heated debate between British and American policymakers over the relative merits of their post-coup policies. The US method for discouraging extremism had focused on establishing close and friendly relations with the junta; Britain, on the other hand, had followed a more reserved line. ${ }^{29}$

\section{The American Hopes for the New Regime}

The early American reports about the junta and Ali Maher's performance were optimistic. The performance to date of Ali Maher-military team, judged in the light of overall American interests in Egypt and the Middle East, had clearly been good. Divergences between the two sides of the partnership had so far been successfully compromised, extremes had been avoided, law and order had been maintained and a start, at least, had been made in attacking the corruption and social injustice which had spread like malignant throughout the body politics.

Sober reflection precludes optimism about the future of Egypt. Little lasting improvement in the living standards of the mass of the people could be expected without a significant change in the ratio of population to resources. There were undeniable possibilities for expansion of the agricultural production and development of industry, but both these means 
would be long, hard, and costly to realize. On the other hand, there were no signs of any slacking off in the rate if population increase-estimated to be on the order of 2.5 percent per annum. ${ }^{30}$

Recurrent and increasingly serious differences between Ali Maher and the Military clique headed by general Naguib were not to be discounted as a distinct possibility. When and if a parting of the ways was peached, the military might find the direct assumption of political power in escapable. Such a development would increase the problems arising from the general lack of political, economic, financial, and diplomatic training among the military group.

Whether or not the situation came to that, the movement could not survive with its aims intact unless a broad base of popular support could be organized. That posed the question of whether the attempt to build such a base should be made in collaboration with an existing organization Wafd and the Muslim Brotherhood were the two obvious possibilities or whether an entirely new arty organization should be attempted. The US expected that the movement would face the continual threat of opposition from dispossessed elements, as well as the danger of competitive bids for popular leadership from the communist front and other extremist organizations who could be expected to be on the lookout for any opportunity to seize control of the revolution which had been set in motion. ${ }^{31}$

Another danger was that of a reaction of disillusion if popular expectations were raised far beyond the possibility of fulfillment. As through the domestic problems were not formidable enough, the new leaders of Egypt had simultaneously to face the chronic problems of Egyptian foreign policy-British occupation and the future status of the Sudan. While there had been a willingness on the part of the leaders to participate in a the Middle East regional arrangement under certain conditions, distrust of the British and fear of their intentions was widespread among the military as among the general public.

Notwithstanding all the foregoing, there was one fact that had to be counted as clear gain both from Egypt's point of view and that of the Western powers. The Egyptian movement consciously aimed at peaceful social revolution designed to undercut and foretell the chaos and outright communist takeover towards which the country seemed hypnotically drifting. If the movement succeeded in that aim, the fondest hopes of the West for stability in Egypt and the Middle East would have been given a new possibility of realization. If the forces of dissolution prevailed in Egypt, America, and its allies might well be forced to write off a large portion of western Asia and North Africa to the Communist orbit. If the situation in Iran continued to deteriorate, the importance of Egypt would increase proportionately. ${ }^{32}$

In formulating American policy towards Egypt and its new leadership, the US found it important to obviously made a balance between the dangers and advantages of caution against the perils and the possibilities of extending encouragement and support to a group which was almost, but not quite, as long on problems as it was long on course, conviction, and determination to see the job through. ${ }^{33}$

Not only were the American reports with the new regime, but also the Israeli once. Although the Israeli government's view that it was too early to tell in what direction Egypt was headed, but expressed its view that the loss of king Farouk was not necessarily a disturbing factor from Israel's point of view since Israel believed that Farouk had adopted an intransigent attitude towards Israel and that he had in fact instructed his diplomatic representatives no to think in terms of EgyptianIsrael peace.

Some Israeli representatives had been in touch with certain leading members of the Wafd. These contacts had taken place both before and just after the coup. The Israeli impression that the Wafd leaders were not averse to a settlement between Egypt and Israel on the basis of there being no real disagreement between Egypt and Israel and the desirability of liquidating unnecessary Egyptian commitments. But the US admitted that it was difficult to tell whether the contacts between the Israel representatives and the Wafd leaders were sincere or whether they were simply light oriental platitudes of individuals who had no governmental responsibility. ${ }^{34}$

Mr. Abba Eban, the Ambassador of Israel to the United States met with Mr. Hart, from the US State Department on July 31 at the former's request. Eban brought himself to the main point of the discussion. He said that Israel hoped that the new regime in Egypt might offer a way for the Egyptian- Israel peace. He hoped that the United States would find it possible to make clear to General Naguib that the United States favored such a peace and that it would be in Egypt's interest as well as in the interest of stability in the Middle East for peace to be concluded. Eban remarked that the American Ambassador to Cairo, Caffery enjoyed a position of highest respect and confidence in Egypt and that he has an extraordinary influence on Egyptians of all political parties. Eban believed that with this position Ambassador Caffery was in an excellent position to counsel the new regime with respect to peace with Israel. ${ }^{35}$

The Department's representatives desired to see a settlement reached between Egypt and would use any appropriate opening to further that end, but they could not tell at that moment whether an opportunity would be forthcoming at Cairo. While the Anglo-Egyptian problem might not have priority over the Israel question, it had to be said that the Egyptians appeared to be more anxious to see a solution to the former than to the latter. ${ }^{36}$ 
The US President imagined that reaching an Anglo-Egyptian tentative agreement regarding the evacuation and future maintenance of the Canal Base would pave the way not only for peace with Israel but also to joint military defense with the West. America was ready to assist Egypt materially in fulfilling its new role which nature had accorded her as a keystone in any structure which might be built for the defense of the Middle East." ${ }^{37}$

In response to the American hopes, Naguib clarified that American initiative in the establishment of the Israeli State and the resulting Arab refugee problem had led to increased anti-Western feeling throughout the Arab countries and has embittered, in particular, Arab-American relations. Naguib assured that the Egyptian government could risk setting these international questions without first creating a firm domestic base on which it could still stand. The Free Officers were planning to urge the US to fund their big economic project, the High Dam. ${ }^{38}$

\section{The Revolutionary Tribunal}

With the formation of the Revolutionary Tribunal (Mahkamat al-Thawrah) in September 1953, the officers for the first time hinted at a willingness to resort to naked force to establish their dominance over the political process. Their intent in bringing old-guard political figures to trial for treason before a court empowered to decree capital punishment was at once to shock unrepentant liberals and monarchists into submission and to unite the general public around the revolution. The new tribunal tried defendants accused of conspiring with foreign powers to sow discord, unsettle the revolutionary regime, and bring about a return of royal or corrupt party rule. Unlike the Treason Court, a mixed civilian-military tribunal, three members of the Revolutionary Command Council, Baghdadi, Sadat, and Hassan Ibrahim, sat as sole judges. Within a week of Salim's announcement the government arrested eleven leading old-regime figures and placed Nahas and his wife under house arrest.

With the trial of Fuad Sirag al-Din, the Revolutionary Tribunal entered an entirely different phase. When Sirag al-Din faced the court in December none pretended that it was not the Wafd, in the person of its most powerful and controversial leader, that stood accused. The case against the Wafd boss, the man described as the power behind the party's throne, consisted of five major counts: illegally benefiting from road paving as transport minister in 1945, accepting a $£ E 5000$ bribe, conspiring to obstruct the investigation into arms racketeering during the Palestine War, allowing the king to transfer funds abroad illegally, and conspiring to corner the cotton bourse, the last four counts between 1950 and $1952 .{ }^{39}$

The tribunals ended the political role of the Wafd leaders but did not end their hopes for a political crisis that would threaten the new military regime and revive their dreams to return to power.

\section{The March Crisis}

Within weeks of the proclamation of the Republic, there were rumors of disagreement within the regime between Naguib and the Revolutionary Command Council (RCC). The split had arisen largely because Naguib, having become both President and Prime Minister and increasingly aware of his personal popularity, began to feel that he should have more real authority. He was no longer satisfied with the role of figurehead. The junta from their side objected that Naguib often made public statements of policy without getting their prior approval and sometimes without the full knowledge of the facts. ${ }^{40}$

Naguib wanted the more personal authority to dismiss and appoint ministers and army officers. He demanded a form of veto over decisions of the cabinet, of the Council of the Revolution and of the Commander in Chief. The junta wanted to maintain its control of policy and its own system of majority vote.

On February 12, 1954, there was a clash at Cairo University between armed Muslim Brothers and students supporters of the Liberation Rally. The government reacted immediately by abolishing the Brotherhood and arresting several hundred of its leading members, including the Supreme Guide. On February 23, 1954, Naguib submitted his resignation in a letter to the council of the revolution. Naguib was counting on both his popularity in Egypt and his key position in dealing with Sudan as he was about to fly to Khartoum for the inauguration of the Sudanese parliament five days later.

Nasser's first reaction was to play for time. But the next day the Council met without him and, some officers voted to remove him. That night, while Naguib was at home his house, was surrounded by troops and his telephone cut. He was put under house arrest. ${ }^{41}$

The news of Naguib's removal brought big popular demonstration in Cairo in his favor. They were organized by the remaining cadres of Wafdists and the left wing groups who, with the Muslim Brothers, could still bring masses of students and workers on the streets. This united Front of Brotherhood, the left, and the Wafd aimed to use Naguib's popularity in the hope if forcing the junta to restore the political parties, parliament, and a freer press. But more worrying to Nasser than this massive support for Naguib in the streets was the split created in the army and inside the Council of the Revolution itself. ${ }^{42}$

To avoid the split spreading through the army and destroying the power basis of the revolution, Nasser persuaded the Council of the Revolution to compromise. Khalid Muhi al-Din was to become Premier and Naguib was to be asked to come 
back to President. While demonstrations continued in the streets and Naguib was kept in unknown place, and an official Sudanese delegation flew to Cairo to urge Naguib's release and safety, a new compromise was proposed. Naguib should return as President but with Nasser as Premier instead of Muhi al-Din. ${ }^{43}$ On March 9 Nasser handed over the premiership to Naguib until free elections should be held. On March 25, the Council of the Revolution majority voted to issue a communiqué announcing the restoration of political parties.

Commenting on the crisis, the US reports mentioned that while the situation appeared calm on the surface in Cairo, a certain underlying tension undoubtedly existed. A strong current opinion existed among the Free Officers in favor of a get-tough policy involving ruthless suppression of the opposition and indefinite postponement of elections. These opinions were being expressed more and more openly and would appear to be having their effect on the RCC.

The Wafd was coming out into the open more and more in its opposition and appeared to be gaining in strength. In the same way, the Muslim Brotherhood appeared to be regaining confidence following the recent RCC-Naguib split and the consequent weakening of the regime's position. The communists were naturally seeking to exploit the situation to the utmost.

Even if disturbances should occur, the embassy was inclined to believe that the RCC backed by loyal elements of the army would retain control of the situation. In such an event, however, it was possible that the result would be a tighter and tougher military government.

The US expected that an early Anglo-Egyptian settlement would undoubtedly do more than any other single to stabilize the situation and consolidate the regime. This fact was appreciated by the Wafd which was violently opposed to any settlement of the Anglo-Egyptian question with the military regime because this would strengthen the regime and blast Wafdist hopes for a return to power. ${ }^{44}$

On March 25 statements by the principal antagonists of the regime, the Wafd and the Muslim Brotherhood, appeared in the Cairo press. The statement of a source in a position to speak for the Wafd was a clear bid by that group to participate in the forthcoming constitutional life. According to that source, the Wafd gladly accepted the principal accomplishments of the Revolution, namely, the establishment of a Republican system of government and the passage of the agrarian reform Law. In addition, the immediate return to parliamentary life was strongly advocated. In many ways, that was a reply to Naguib's statement of the previous day. ${ }^{45}$

The professed intention of the Wafd to accept Naguib's leadership and thereby exploit the bad feeling between Naguib and the RCC was quite clear. These statements demonstrated that the Wafd and the Brotherhood both apparently believed that the political situation deteriorated to the point where their public pressure would have some influence on ensuring events. If these statements were an indication of the pressure that was building up, at least, three opposing forces would be present. The Brotherhood opposed to the old politicians, but not the RCC so long as the dissolution order was rescinded. It asked only to be restored to its previous position. The Wafd apparently hoped to have a significant role in Egypt's political life along with Naguib.by accepting agrarian reform law and the Republican system, the Wafd assured its traditional support from the peasant and avoided the accusation that it was reactionary.

As Nasser had planned, the announcement of the impending self-dissolution of the council of the Revolution came as a shock to all those in the army and on the public who had opposed the old regime and feared its return to uninhibited power. Acting through the Liberation Rally and the Trade Unions, Nasser was able to canalize this feeling into large demonstrations demanding the maintenance of the Council and calling for Nasser instead of Naguib. ${ }^{46}$ On April 17, Naguib was forced to resign as Prime Minister, keeping him only as President. Increasingly he became figure head until his final removal from office in October.

With Nasser's return, the elections were again postponed until the end of the three years' transition. Once more political parties were banned and the press censored. Thirty-eight former ministers and twenty-three journalists were deprived of political eights for ten years. The only concession to democratic sentiment was the creation of the National Advisory Council ( NAC) of 240 members appointed by the Cabinet. The tight control over the press, especially the suppression of the famous Wafdist newspaper al-Misri and the other journals, had aroused the resentment of the Egyptian intellectual. ${ }^{47}$ With this return of Nasser to full power, the Wafd believed that the internal crisis would not be the tool to depose Nasser. The Wafd leaders believed the external crisis would be the possible way to achieve this goal. The escalating upcoming incidents with the US thought to be the light of the dark tunnel.

\section{Egypt-US Tense Relations in 1955}

The year 1955 was to have a lasting effect on the relation between the United States and Egypt. Since 1951, the US has had felt that some type of mutual security arrangements was necessary for the Middle East area to preclude the possibility of a Russian attack in that direction. 
Baghdad pact of 1954 (included Turkey, Pakistan, and Iraq) was the American tool to achieve her goal. Gamal Abdel Nasser. Moreover, advised the West that mutual defense pacts between the Arab world and the West would have to wait until the Arabs overcame their residual suspicion of the Western imperialistic intentions. The reaction in Egypt was direct and disastrous to American objectives. Through 1954, the Egypt wanted to strengthen to be the Arab World to defend itself against local attacks by Israel or a Soviet thrust. In January 1951, the Egyptian Foreign Minister, Mahmoud Fawzy, was highly critical of the Baghdad Pact. Nasser saw Baghdad Pact an attempt by Britain to regain the political influence she had lost after the Canal agreement. ${ }^{48}$

The Israeli attacks on the Egyptian military positions in Gaza since 1955 were the reason for the tense relation between Egypt and Israel. Despite the strong language of American officials and censure resolutions through the United Nations, no sanctions were invoked against Israel. The United States policy at this time was to handle the Arab-Israeli dispute completely within the confines of the United Nations. The Israeli attacks pointed up the military weakness of Egypt. Up to this point Nasser seemed to concentrate on the internal social and economic reforms, but now the situation changed. ${ }^{49}$

After the Israeli attacks on Gaza, Nasser no longer allowed a lapse or delay in obtaining the needed arms. In the first week of June 1955, Egypt requested arms from the United States; the amount was supposedly for less than \$20 million. In September 1955, while State Department announced that it was willing to sell arms to Egypt on credit in order to offset Soviet offers, Nasser announced in Cairo a commercial agreement with Czechoslovakia to supply Egypt with arms. He mentioned that that agreement would permit Egypt to pay in Egyptian products such as cotton and rice. ${ }^{50}$

Since the West had continuously denied Nasser's earlier requests for arms and he was in desperate need to defend his county, he signed the Czech Arms Deal, that was described on October 15, 1955, by The British Chief-of-staff as a Soviet attempt to preempt the Baghdad Pact and establish a strong political presence in the center of the Middle East, namely Cairo. $^{51}$

Another important factor that deeply affected the US-Egypt relation in 1955; after attending Bandung conference in April 1955, Nasser returned to Cairo to openly proclaim his new doctrine of positive or neutralism, non-commitment to either of the conflicting world blocs. Again, the US officials believed that Nasser would not be their tool to achieve their objectives neither with Israel nor against the Soviet.

The US-Egypt tense relation clearly was shown in an interview with the Lt. Col. Zacharia Muhi al-Din, the Minister of Interior, and the Reporting Officer in the American Embassy on 19 June 1955. Muhi al-Din mentioned that the conflict of Egyptian- American policy on the subject of the area defense was of basic importance. As long as the US supported the Turk-Iraq Pact Egypt had to suspect American motives in very another phase of relations between the two countries and anticipate American pressure upon itself and the other Arab States to join the Western alliance system. There were, in fact, other reasons for Egyptian suspicion of the US, among which were the US cotton policy, broken promises by the US to provide arms aid and to facilitate the Egyptian purchases of arms in the US, and the hostility of many Americans to the Egyptian regime since the Turk-Iraq Pact.

The American Ambassador to Egypt, Henry Byroade saw that Nasser found himself in a dilemma in that his fundamental desire to associate Egypt more closely with the West seemed to him constantly frustrated by "Western policies" which made it increasingly difficult for him to justify a pro-Western attitude to his essentially nationalistic followers. Through Baghdad Pact, the United States was clearly the most dangerous to Egypt, for if the states bordering on Israel to the North and West were to be persuaded to join the Northern tier and make peace with Israeli, Egypt would be left alone. In this case, the Egyptian Revolution would be threatened with destruction through military defeat or a dishonorable peace settlement. ${ }^{53}$

Byroade accounted for this feeling by the assumption that Nasser was not yet prepared to burn his bridges to the West. He said there were, at least, two reasons why America would look upon him and his government with favor. In the first place, he was relatively powerful and free from the influence normally hampering Middle Eastern politicians. In the second phase, he was one of the few leaders whom the US knew who was really sincere about bettering his country and particularly the conditions of his own people. While the American Officials would wish he were not so obstinate in certain foreign policy matters, these assets alone were enough for the United States to regard him in a benevolent and friendly manner. ${ }^{54}$

\section{King Farouk and the US Relations after the 1952 Revolution:}

The American newspaper reported in July 1952 that US government might be preparing to permit the deposed King Farouk to come almost immediately to the United States. In a step to show the interest of the US to have a strong tie with the new regime in Egypt, on July 30, 1952, a letter was sent from Mr. Broune from the Near East Department to the US Department of State urging it to first obtaining the views of the new government of Egypt, to avoid terrific reaction against the US and its position in Egypt and possible other parts of the Arabic world; which he described as could have lasting and disastrous repercussion there. In his thought there were many reasons for his demand: ${ }^{55}$ 
- Farouk was generally hated in Egypt and to offer him asylum well might leave the impression in Egypt that the US government supported him and his cause unless first the American government would ask the Naguib's government what its attitude would be towards the proposed visit.

- Approaching the Naguib's government before Farouk's visit would undoubtedly strengthen the US position in Egypt, particularly if the US put it on the grounds that it would undoubtedly work towards the welfare of the Egyptian people to have the young King brought up in the American tradition as well as to have Farouk exposed to American democracy.

- The US should maintain a firm footing with both the Wafd party- the people's party- and the Naguib's government as long as the Free Officers were operating in alliance with that party until the US had been forced by development to do otherwise. - The Free Officers gave the impression that they would have no objections to entering into a Mid-East Defense Pact once the British relinquished their hold in Egypt. As a matter of fact, if the British got out of Egypt voluntarily, it would not be long before their stock would rise to a new peak with the Egyptians, just as it has with the Indians since India's independence, and they well might soon have troops back in Egypt along with those of other Western nations by request.

- The young officers' movement might be the most hopeful thing that could happen for Egypt, particularly if they went after corruption in the government as they have intended to do an institute of general reforms.

- The Free Officers would have no objections to having US troops in Egypt if this was regarded as necessary. Until such time as the British leave Egypt and relinquish all claims, they regard the British as enemy No 1. Next they feared and dislike most the French and the Turks. They regard America with hope, some suspicion because of the US apparent support of the British against Egypt, and would welcome an arrangement which would put them on a more friendly basis with the US.

The letter showed that the American benefit with the new military regime in Egypt was the determining point in any possible relation between the ex-King Farouk and the US. Soon, in 1955, some other opponents to that American policy appeared. The Chairman of the Troy World Communication sent letter to the Secretary of State, John Foster Dulles, on March 4, 1955 telling him that as an outspoken American writer, he was seeking to stem the ill feeling which was daily being built by the Arab Nations, and which was weakening the US friendship with the Middle East. He opposed to Nasser, who in his opinion, had the ability to grasp the reign of the Arab world, holing bait over the Western and Eastern Powers. He strongly opposed to Nasser attaining the leadership of the Middle East, believing that Nasser's actions would cause the western powers to crawl to his every wish before a short period of time in regards to all important questions of the Suez and the Middle East.

Troy believed that with the support and sentiment of the cunning Indian Prime Minister Nehru, that vast area could soon be increased to anti-western feeling, creating a vacuum so weakening to the US position in many of these virtual areas.

Troy claimed that ex-King Farouk could be re-instated in the hearts of many by the proper actions, attention, and support of the proper parties. Re-uniting with his former wife, Queen Nariman, along with their son prince Fuad, a visit by the United Royal Family to Britain and America could ensue, with a complete joining of the Dowager Queen Nazli of Egypt and Royal Princesses in New York.

Troy advised commencing a visit to the United Nations, Diplomatic functions, etc., with both sides acknowledging appreciations and friendship of the past years when friends during World War II.

According to Troy's understanding and knowledge of Islam people, he was certain beyond doubt that the royal visitors and family then touring Europe, Turkey and parts of the Middle East, under proper arrangements and directions, could create a force of power which could eventually lead back to the throne of Egypt, defeating the dictatorial power of Nasser and his Military controlled country. He ensured that this silently would take place under the US direction. ${ }^{56}$

That opinion of the writer was not under a demand of Farouk, as the American documents approved that the ex-king did not prefer to talk about Egypt and the new regime since his departure to Rome in 1952.

The first direct contact between Farouk and the US was on the evening of November 4 when ex-king Farouk of Egypt paid an unexpected visit at the home of the American embassy officer in Rome whom he had met casually six months previously at a party at the Open Gate Club. Farouk arrived at the officer's house unannounced and unescorted, driving a small Italian car with Rome license plates. (Farouk usually used to drive a large Mercedes with Italian CD license plates and it was assumed that by coming in a small, unidentifiable car, he desired to avoid attracting notice).

Farouk remained more than two hours chatting with the Embassy officer, Welles Stabler, Second Secretary of Embassy and his wife. During the course of the conversation, much ground was covered, but at no time did Farouk make any request or outwardly seek information. He repeated that what was happening in the Near East was "No longer my baby".

While the reason for Farouk' visit was unclear to the US embassy, the Department of State expected that he might be paving the way for close contact with the embassy in the event that the situation in the Near East, particularly Egypt, took a turn which might, in Farouk's opinion, favor his interest. As far as it was known, this was the first time Farouk had been in touch with the embassy since $1952 .{ }^{57}$ 
The report mentioned that Farouk seemed in high good humor and ready and willing to talk about a whole range of topics. He drank a glass of tomato juice, ate several pounds of salted almonds, and appeared in a relaxed and jovial mood. Aside from one or two rather coarse sallies, his conversation was interesting and often concise. He spoke in an affectionate manner of his manner of his children (at school at Vevey and in the winter at Zermatt), and mentioned his wife once, but not by name. The following were the various topics were covered during the conversation: ${ }^{58}$

\section{The Middle East situation:}

Farouk expressed great concern with development in the Middle East and said he feared the situation had earmarked of prelude to a general conflagration. The situation had got out of hand and the western powers were considerable to blame for what was happening. Farouk wondered whether the Egypt-Israel fighting might not blossom into a resumption of full-scale war with the possible result that the gangsters in control in Egypt would be forced out by a revolution. Farouk said that the difficulties within the Arab World and the attitudes of the Arabs towards the West would not be what they were now if he were still in his country. He had been able, and often did, exercise a moderating influence on his Arab colleagues and they had been willing to listen to him. He had had many means at his disposal to accomplish this objective. That moderating in influence no longer existed. Farouk said he would never regret having gone to war with what was called the Jewish State (he never used the word Israel), and he was and would always be, the implacable foe of the Jews. Sooner or later the Jewish State in the Near East would be destroyed and Palestine would be divided amongst the Arab States. He recognized that there would always be a Jewish problem and that after the Jewish State had been destroyed, the wandering would begin again until some other place had been found for the Jews to start another state. Farouk prophesied that even the United States would sooner or later see pogroms which would make Hitler's experiment look tame.

\section{Farouk's attitude towards the US:}

Farouk expressed considerable bitterness towards the US policy which he said had been responsible for his departure from Egypt. He insisted that the US representatives (and he named no name) had been in touch with Nasser and his colleagues, and had given them the green light to go ahead with the coup in 1952. Farouk said that he could have presented documentary proof of what he had just said, but that he had refrained from doing so in order not further to complicate relations with the US and to permit the US to make amends when it realized its mistakes. Farouk stated that he had unpleasant memories of his meetings with President Roosevelt in 1945 since Roosevelt had dived into Jewish question without even the usual preliminaries of diplomacy. Farouk had made clear to the President that his attitude towards the Jews was one of principle and that he neither could nor would change his principles. He told me that perhaps his recollections of the Bitter Lakes meeting had had their share in his decision in 1948 to fight the Jews.

\section{The British:}

Farouk said that he knew that at least three occasions the British had tried to have him assassinated. Farouk said he blamed the British in good measure for the fact that Nasser was dealing with the Soviets. The British had forced his hand during the war and he made him accept a Soviet representative. He had pleaded with the British not to insist, but they had and were now reaping the damage.

\section{The French government:}

Farouk said that the French government was most cordial to him. About four months ago he had released a declaration on his attitude toward Egyptian affairs through a French News bulletin. He had obtained the complete approval of the French government beforehand. In fact, the French had offered him time on the radio network if he had desired. Farouk thought that the French would much prefer to have him back on the throne rather than to have to cope with the excesses of the present group in Cairo with regard to North Africa.

\section{The Sudan:}

Farouk said that the only thing that had kept the Sudan attached to Egypt was his person. His departure had meant the loss of Sudan to Egypt and that was now what was about to happen. The tragedy of the situation was that someday the Sudan would try to cut off the Nile waters from Egypt and then would have no resources but war. Farouk said that the Sudanese soldiers were better than the Egyptian. He might not be so intelligent, but he was a better fighter and loyal. Farouk said that he knew this well since Sudanese troops had fought for him the day or so before he left Egypt.

\section{Why did he leave Egypt?}

Farouk said that he had left Egypt to avoid bloodshed. He could have decided to stay and there would have been heavy fighting with many killed. In all probability, he would have succeeded, but the instinctive attitude of a ruler was regard for the welfare of his people, and thus he had taken the way out which would be less difficult for his people. He linked his 
attitude to that of Umberto who could also have stayed and fought the fraudulent referendum. He had chosen to spare his people a civil war.

\section{The Muslim Brotherhood:}

Farouk said he had recently heard that the present regime in Cairo had let many of the Muslim Brotherhood out of jail and he assumed this was done to provide assault groups for the fight against the Jews. He recalled that he had many a difficult time with the Muslim Brotherhood who had cost him several Prime Ministers and had threatened his life. Farouk said that he had obliged, after the most careful thought, to order the liquidation of Supreme Guide, Hassan al-Banna. The job had been done very skillfully by his agents, and while the Muslim Brotherhood had pointed the finger at him, they never could prove he had been behind it. Farouk stressed that his decision to liquidate Sheikh Hassan al-Banna was necessary to remove the evil influence of that group. He had been on the Muslim Brotherhood's murder list for three years during which he had been most careful, surrounding himself with some very good boys. Later his relations with the Muslim Brothers had improved and his name had been removed from the list.

\section{The Saudi Arabia and Yemen:}

Farouk said that he was sorry the way things were going in Saudi Arabia. He felt somewhat responsible as he had brought Saudi Arabia into active participation in Arab World affairs. Now, however, they were showing signs which did not augur well for the future of Saudi Arabia. He said that he was convicted that the Saudis were carrying on the Buraimi affair more out of spite of the UK and US than out of interest in the area. On the other hand, if there were no oil at Buraimi, nobody would think twice about it. Farouk said he was amazed that the Yemen and the Soviets had signed an agreement. He had no idea what was in the agreement although he assumed it must be in the simplest terms for the Yemenis to understand. He said that he had known Prince Abdullah very well and that he had warned the present Imam some time ago that Abdullah would try some day to pull a coup. Farouk said that Abdullah used to stay at the palace in Cairo, and when drunk, he would let all sorts of things out of the bag which was duly reported to Farouk, Farouk said he thought the Imam owed him some sort of debt for having warned him against Abdullah.

Iraq:

Farouk said that notwithstanding rivalries with Iraq, he had to admire the Iraqis as men. They had chosen their own policy course, and he implied full approval of Iraq's adherence to the Iraq-Turkey-Pakistan- Iran Pact.

\section{Israel Prime Minister's Talks with the Secretary of State in Paris:}

Farouk said that he had received a great deal of pleasure by what he had been told about Sharett's talk in Paris with the Secretary of State. He had heard that Sharett had intimated to the Secretary that Farouk, as king of Egypt, was considerably better to deal with than what was now ruling Egypt. Farouk said that even though the Jews knew him as their unrelenting enemy, they also realized he had certain scruples ad principles. The only time he mentioned his wife while he was talking about the Spanish Head of State. Farouk doubted that Francisco Franco would play much of a role in the Near East since Spain was far removed from the scene. On the other hand, Franco owed a certain debt to the Arabs, as it was Arab of Spanish Morocco who had helped him gain power, and this Franco had not forgotten. Farouk said that he had never met Franco, but that his daughter had been entertained at tea at the palace in Cairo "by my wife".

\section{Radio Free Egypt:}

He said it had improved its strength and mobility, and was, he thought, nothing a good job, broadcasting in Arabic and English. He said he did not know its location, etc., but he clearly showed he was more than interested in the Station's existence. Although the purpose of King Farouk's visit was unclear for the US officials, it was clear for himself. Farouk chose this critical year of the tense relation between the US and Nasser, to talk about all the situation in and outside Egypt. He wanted to ensure that if the US gave the green light to depose him from his throne for Israel, the new regime would not achieve the American goal. And what the US thought to be allied in the Middle East, pushed the situation to be out of the American hands.

\section{The Wafd and the US Relations after the 1952 Revolution}

The Military Officers were facing a series of potential problems. Once was the constitutional issue. According to the article 51 of the 1923 Egyptian constitution, the Regency Council could not assume office except after swearing an oath of allegiance before both chambers of parliament. This meant that the Wafd would have to assume its responsibilities as the majority party in the last parliament. It was difficult for the young officers to compete with the old popular political party. The matter of the Regency Council was a warning sign to both the military and the Americans. Caffery did not hesitate to express his fears that " it would, however, seem inescapable that both houses must be convened before the Council of Regency can take over...a session of the former Wafd part controlled Parliament and this time, it might not be in our 
interest ${ }^{\prime 59}$ For the Americans, the military government could possibly be useful in furthering the concept of a Middle East Command, but it would be difficult for the Wafd government to present a reasonable position on these issues. American fears of the Wafd returning to power at this power early stage of the revolution led Dean Acheson to express the State Department's view to his representative in Egypt that he should make clear to Naguib our hope that the constitutional problem can be resolved as soon as possible... our concern at the possible return of the Wafd, who are fully implicated in graft and corruption". ${ }^{60}$

The Americans began to encourage the rift between the two sides by stirring up competition between middle-class army officers who belonged to anti-Wafd organizations, and the Wafd Party. On July 28, 1952, the New York Times tried to provoke the anger of the new regime against the corrupt Wafd by saying that there were no reports of any move against members of the Wafd Party as part of the promised drive against corruption.

The officers received the willing collaboration of leading jurists such as Suleiman Hafez and Dr. Abdel Razik al-Sanhuri, who in their legal opinion afforded the officers a golden opportunity for the destruction of the Wafd and the whole constitutional system. Their legal interpretation that there was no need to convene parliament lent a legal authority to the officers' act of power. With the legal backing, it was natural that the army was going to make the most of this powerful and to assert its authority over Egypt. This State Council decision was much appreciated by Caffery and the Western political circles. Many explanations could be given for the American support of the new regime vis-à-vis the Wafd party. Firstly, it was said that Wafd was a prisoner of its own promised and its previous politics. Secondly, the American position was a kind of punishment for Wafdist neutrality during the 1952 Korean War. Thirdly, it was simpler for the US to deal with a small group of officers as opposed to a political party. With a party like the Wafd, its members argued too much for comfort and the debate presented points of view then to be accepted or rejected. Their behavior and actions would be too difficult to predict. Finally, the existence of the Wafd with its crushing majority a popularity would give the military junta a chance to gain any popular support as long as the Wafd was still active if political life. ${ }^{61}$

The last thing London also wanted was the Wafd returned to power, as always happened when free elections were held; its previous administration was blamed for the political crisis which culminated in 'Black Saturday'. In the weeks following the coup Britain pursued a policy of giving Maher 'every encouragement' to keep the military under control while he sought to bring stability to Egyptian politics. Naguib was viewed as moderate but little was known or found out about the younger officers behind him. Maher, in the meantime, tried to give the impression that he was in charge. Two weeks into office he was confidently telling the British embassy that within a year he could dispense altogether with army support. However, by mid-August Britain's ambassador, Ralph Stevenson, who had returned to Egypt after the coup, felt that Maher was in fact little more than a 'political instrument' of the junta. ${ }^{62}$

In spite of these US and UK attitudes towards the Wafd, the Wafdists tried to contact the US, particularly in 1955 to gain their support and revive their hope to return to power after getting rid of Nasser. Muhammad Ahmad 'Abbud Pasha (1899$1963)^{63}$, was a Wafdist parliamentary deputy in 1926 and a major financial backer of the party until Mustafa al-Nahas became a leader in 1927. Abbud resumed support of the Wafd during its final years in power. On March 12, 1955, he met an American reporting officer and told him that he recently had a long talk with Nasser and Amer about what Egypt had to gain from its new arrangements with Syria and Saudi Arabia. He told them that all of the excitement over the Turk-Iraqi Pact had done nothing to help business.

The American report commented that it would be surprising if Abbud Pasha thought on any other line. His large business connections with the United States and the United Kingdom cause him to be completely pro-Western in outlook. On the other hand, his genius for survival, even under the RCC Regime, had rested in part upon his capacity for keeping his mouth shut. If he did speak to Nasser as he said he did, it would be a display of some courage on his part. Abbud was one of those Egyptians who believed that only troubles had come from Egypt's dabbling in Arab affairs. They believed that Egypt would be more prosperous and more respected if it moved away from Arab politics and concentrated on its internal problems. ${ }^{64}$ This American report gave a good impression about how the US would reply on the Wafd's attempts to contact it.

\section{The US' Critics to the New Regime in 1955}

Speculation over the possibility of the regime convening the National Advisory Council NAC, initially to have been established in April or May 1954, had been stimulated by American reports that the list of prospective candidates for this council was once again being revised. From February 13 until February 27, 1955 Major Ibrahim Tahawi, Director of the Liberation Rally; Abdullah Toema, Assistant Director of the Rally, Ahmed Baquri, Minister of Waqfs and Ahmed Sharabassi, the Minister of Public Works, toured Upper Egypt reportedly for the purposed of recruiting prominent citizens for membership in the Liberation Rally.

In each province this group selected for membership in the Rally approximately fifty prominent citizens from among the Omdahs, local officials and distinguished families. Those individuals who agreed to join the rally at the special invitation of 
Tahawi were informed that within few months the National Advisory Council would be set up and that the NAC members representing the respective provinces would be selected from among the prominent members of the Rally in each province.

Between March 14 and 24, Toema, Baquri and Sharabassi toured Middle Egypt and Fayum for the identical purpose, and it had been reported that they would shortly visit the Delta area in order to offer this proposition to select individuals in Lower Egypt.

Concerning the possibility of the NAC being convened at some future date, a usually reliable regime source had stated to the American Embassy that in spite of the activity of Tahawi and Toema, it was doubtful that this Council would ever be established. He pointed out that according to the original plans of the RCC, the National Advisory Council was meant only as a temporary assembly that would be terminated with the conclusion of the traditional period of January 1956. He maintained that Nasser hoped to make certain alterations in the government in January 1956, and, for this reason, the National Advisory Council had become an unnecessary step in the return of Parliamentary Democracy to Egypt. ${ }^{65}$

With respect to the travel of Tahawi and Toema, the source said that in the process of selecting new members for the NAC, they were attempting to determine the feeling of the rural areas. Furthermore, by selecting as candidates for the NAC only individuals who had publicly accepted Rally membership, Tahawi had strengthened the Rally in the rural areas. In concluding, he commented that promises of membership in the NAC were also means of applying additional status of morphine to the rural supporters of the regime whose enthusiasm rights would be dividing.

Old regime politicians and opposition elements had also expressed their views on the possibility of the regime ever convening the NAC. Abdel Aziz Sirag al-Din, a Wafdist who continued to maintain his contacts in the rural areas, commented to the American Reporting officer that he hoped that the regime did establish NAC. He stated that no doubt that the regime plans on the NAC being a rubber stamp that could be used to implement its efforts to control Egypt, but if the Council came into existence, he continued, Nasser would soon discover that he had miscalculated because the NAC would ultimately develop into a source of vocal originated opposition to the regime. Sirrag al-Din claimed that many of the persons recruited by Tahawi and his associates were Wafdist and Saadists who might appear to be accepting the regime, but who in reality retained loyal to their old party allegiances. ${ }^{66}$

In a more caution manner Mohamed Hussein Haykal, President of the Liberal Constitutionalist Party and former exPresident of the Senate, privately stated many of his former acquaintances had agreed to be members of the NAC. He said that the true feeling of these persons and their sympathies did not lie with the present government even though they had never taken part in any activity against it. His conclusion was that the NAC, with its present prospective members, would never give the regime very much support.

In a private discussion on March 14 with a group of American Journalists visiting Egypt during a world tour, Salah Salem stated that following the termination of the three-year transitional period in January 1956, another transitional period of five years duration would be inaugurated. During this second transitional period, Salem revealed, Egypt would be ruled by a single party government, and after the five years steps would be taken to gradually adopt a more democratic system of government.

In a press conference with a delegation of Indian Journalists on March 22, Gamal Abdel Nasser stated that the Free Officers would never be responsible for establishing a false democracy. They had, therefore, decided not to have parliamentary elections immediately because the capitalists feudal landlords were still in apposition to control a very large number of voters and thus come into the new parliament in very substantial numbers Nasser said that they had to, therefore, wait until complete liquidation of the influence of the capitalists and the vest interests has been brought about. ${ }^{67}$

Since January 1955 when the RCC brought itself to a stalemate over the question of preparing for the return of parliamentary government, the regime has come to closer to agreeing on a mean for regulating its domestic position after the end of the transitional period in January 1956.

The US saw that since January 1955, the regime has concentrated its attention on such foreign policy issues as the Turk-Iraq Pact, the increased tension with Israel, the Afro-Asian conference and the Syrian-Egyptian-Saudi Joint Defense scheme. In none of these issues, however, had the regime realized any gain or achievement that could be used to offset its failure to reach an agreement within itself about the manner in which it planned to govern Egypt in the future. In fact that none of the regime's plans for economic development were being realized were a very rapid rate had to be equally disappointing to the leaders of the Revolution. The recent past, therefore, had not provided substantiate that could be presented to the public as a compensating factor if the regime discovered that it could not keep its promise to end the transitional period in January 1956.

For the US, Nasser's statement was an open admission that the regime had not received sufficient acquaintance from the people to win the free election. It was true that in speaking to the Indians, Nasser qualified his lack of enthusiasm for 
elections with the remark that his adherence to false democracy prevented him from holding controlled elections. This, however, was only a stated motive of the Prime Minister which might be nothing more than a rationalization, whereas his refusal to schedule elections was a known fact that demonstration Nasser's lack of faith in his ability to successfully hold any kind of elections, free or otherwise. ${ }^{68}$

Also, in Nasser's statement to the Indians was an indication that the use of forceful means by the regime to strengthen its domestic position continued to be a possibility. The statement that elections had to wait for the complete liquidation of the influence of the capitalists and vested interests ( the former Parties) could only mean that Nasser was willing, if it became necessary, to take further measures against his domestic political opponents. Nasser's own admission, however, that his opponents still have influence was evidence that the repressive measures taken by the regime in the past had not placed it in a position where it felt that it could hold elections without serious consequences for its future. In view of the fact that to date suppression has failed as an adequate means of establishing the conditions for a regime election victory, it was difficult to understand why the Prime Minister believed it would be any more successful in the future.

In speaking of a delay in the election and the establishment of a single-party system, Nasser and Salem expressed intentions which were contradictory to the regime's long-standing promise as the revolution of the people to establish a freely elected parliament in January 1956. Members of the RCC apparently believed that they could not safely hold any elections, the easiest way for the regime to keep its promise without creating a threat to its own existence would be to alter the form of government only to the extent necessary for it to be able to claim that progress was being made along the road to democratic government. This approach would be strengthened if the regime could demonstrate that fulfilling the promise had been delayed by the irresponsible actions of the capitalist feudal landlord opponents of the regime. Their liquidation could then be carried out as necessary preliminary to the establishment of some form of legislative or more probably consultative body, perhaps based on the single party system. ${ }^{69}$

By establishing a single party system, it would be possible for the regime to institutionalize its position and at the same time, with the proper advanced publicity, to create the impression that progress was being made towards the representative government.

It was doubtful, however, that the NAC would ever be used in any regime plan for a single party government because in certain respects the NAC fallen short of the requirements that would be necessary for a single party legislature. According to the new plans, the NAC would not have legislative powers and it would not be based on a party system. For these reasons, the NAC could not be used to give the impression that the regime's base of responsible officials had been broadened by its creation, and because of the manner in which its prospective have been selected, it could not be easily represented as a popular body. Another possible disadvantage was that the RCC could not claim that the NAC actually shared responsibility for governing Egypt. The NAC, therefore, could not be used to diffuse the opposition to the regime which was presently concentrated against the only politically responsibly group within the regime, the RCC.

The US believed that if single party systems were established, the regime would no doubt want to represent it as something new and dynamic. A modified NAC, the idea of which had been lingering in the background for an entire year, would hardly be the suitable vehicle for the new system. It was doubtful, therefore, that the NAC would be associated with any change in the governmental structure that was meant to endure for several years or more.

There was an explanation, however, for the RCCn's interest in the NAC. It would be recalled that from May until September 1954, the regime was continually adding to and revising the NAC membership list in an effort to obtain a group that would best serve the interests of the regime. Tahawi and Toema in their recent visits to the provinces continued that process. They had also attempted to reassure certain individuals already designated for membership in the NAC that it would eventually be convened. In addition, they selected replacements for some previous nominees who no longer desire membership in the NAC or who became persona non grata to the regime in the interim since the members of the proposed Council were first selected. In effect, therefore, the regime had taken the necessary measures during the past year to assure that the planning for the NAC had always been sufficiently current for this body to be convened at a moment notices. ${ }^{70}$

This policy of keeping the NAC a constant state of readiness, combined with the procrastination in actually establishing this council, made it appeared that the NAC was meant to be instituted only in the event of an internal emergency during the remainder of the first transitional period at which time the regime night be required to make hasty concessions with respect to the return of the constitutional government. Associated with the NAC were advantages that it could be established without elections. It could also be more controlled by the regime than a legislative or semi-legislative body which the RCC might otherwise compel by an emergency to constitute in another manner. ${ }^{71}$

The American doubt about a real intention of the new military regime to establish a parliamentary life in Egypt became one of the approaches that the Wafdists followed to critic Nasser's regime. 


\section{The Two Approaches of the Wafd to the US}

Although they had the same objective, they followed different approaches. The friction between Nasser and the US in 1955 attracted the Wafdists to move towards the US to gain their support and get rid of Nasser and his regime. The contacts between the Wafd party and the US during 1955 were divided into two approaches. a) Mahmoud Abu al-Fatah, and b) the Cousin of Fuad Sirag al-Din.

- Mahmoud Abu al-Fath:

He was the founder and the owner of the pro-Wafd newspaper al Misri. ${ }^{72} \mathrm{He}$ was born in August 1894, Mustafa Amin, coowner and publisher of Akhbar al-Yom, claimed that Mahmoud was not a real Wafdist like his brothers Ahmed and Mohamed; as he used to struggle with them. Fuad Sirag al-Din, the Secretary of the Wafd said that any struggle between Nahas and Mahmoud Abu al-Fath used to friendly solved. Many claimed that Abu al-Fatah' marriage to the niece of Nahas pasha cemented his ties with the Wafd. In general no, one could deny that al Misri used to defend the Wafd in most of its difficult situations like the incident of 4 February. ${ }^{73}$

In spite of all critics to its attitudes, Mahmoud continued to support the Wafd till the dissolution of the political parties. Although Nasser cooperated with Mahmoud Abu al Fath's younger brother, Ahmed, the editor of al Misri, shortly after the revolution, the Abu al Fath's interests opposed the establishment of a dictatorship. The opposition irked Nasser to the point that the regime accused Mahmoud Abu al-Fath of treason acts against the government. Al Misri was stopped in May 1954 by a decree of the Revolutionary courts. Both he and his brother, Hussein, were tried, and all of the properties of Abu alFath family in Egypt were confiscated. Mahmoud Abu al-Fath was tried in absentia, was sentenced to 10 years in prison but has never returned. Hussein Abu al-Fath was deprived of properties and was allowed to go free after a period of house arrest. About six months ago Ahmed Abu al-Fath joined his brother abroad and Hussein obtained an exit visa to join Mahmoud in Paris about in $1956 .{ }^{74}$ Mahmoud was away in Europe and stayed there until his death in $1958 .{ }^{75}$

An American document mentioned that in the elections of 1949 which brought the Wafd back to power; Ahmed Abul Fath was elected to the chamber of Deputies, on the Wafdist ticket. During the summer of 1951, he became popular for his attacks on the government-sponsored press bill which was finally defeated in parliament. Ahmed Abu al-Fath was said to be honest, in contrast to his brother Mahmoud who was known to be very corrupt. ${ }^{76}$

On July 5, 1955, Abu al-Fath sent a letter to the American President Eisenhower mentioning that he sent it at the request and on behalf of responsible political, intellectual and religious leaders inside and outside Egypt. He assured that the internal situation in Egypt had not been accurately assessed by the competent experts. This was implied by the aggravation of the internal and economic conditions, on the one hand, and on the other, by the naturalistic and anti-American pronouncements of a regime which had hitherto enjoyed genuine and active support from the United States. ${ }^{77}$

In March 1954, the United States elected to extend support to Lt. Colonel Nasser's counter-coup against the moderate elements in the army headed by General Naguib, and the overwhelming majority of the people, who were clamoring for the re-establishment of constitutional and democratic life. While admitting the totalitarian structure and the abuses of Nasser's dictatorial regime, some American officials, in Cairo, felt that the return to the parliamentary rule might jeopardize the possibility of an agreement on the Suez Canal question and also hinder the continued stability essential for the fruition of plans for economic and social reform. There was also a secret promise that Egypt would subsequently assume the leadership in the promotion of regional Middle Eastern collective security systems within the framework of the Western Alliance. Abu al-Fath said that the Wafdist convinced that only inaccurate information and insufficient data on the Junta rule could have been responsible for the excessive confidence which the United States government have placed in Nasser's popularity, loyalty and statesmanship. Significantly, only a few days after 20.000 Muslim Brothers had been jailed and six of their leaders sentenced to death, Jefferson Caffery, the American Ambassador in Egypt, alleged in a statement published in New York Times that Nasser was enjoying popular support. ${ }^{78}$

About the internal situation in Egypt al-Fath said that a Suez settlement had been achieved, but the stability of the military rule remained fictitious, maintained only by tyranny and violence. Economic development plans had largely not proceeded beyond paper, owing to lack of confidence on the part of foreign investors. As a result of its unpopularity and insecurity, the military regime was compelled to break its repeated promises for closer cooperation politically with the Western Powers and had, on the contrary recently engaged in a demagogical anti-American and naturalistic campaign. By so doing the regime presumably hope to regain popularity with a people who, rightly or wrongly, tend to place responsibility for the continued survival of their oppressors upon the United States and Britain.

Abu al-Fath determined their goal as the Egyptian leaders who participated with him neither expect nor suggest that the Western Powers would assist in the overthrow of the existing dictatorial regime. Such a step would be contrary to national dignity and international practice. It was their firm belief that such a tyrannical political system had to inevitably collapse. Furthermore, the best national interests required that the regime is allowed to die a natural death, with the minimum 
disorder, thus sparing the country the disastrous consequences of violent and chaotic events, which would only benefit the most dangerous elements - the communists.

This was especially looked for from the United States, whose interest in the Middle East and Arab world had never been incompatible with Egypt's, particularly that time that was being made to the North Africa situation. The best interests of the United States in the Middle East were not served, in the past, by a close identification with the polities of European colonial powers. Such interest profited even less from the support the United States gave to military regimes in the Middle East.

Abu al-Fath focused on the Nasser's pro-communist diplomacy might not be entirely motivated by tactical blackmail directed against the United States, but communist infiltration within the junta might have been a greater stimulant of the neutralism than was the Iraqi-Turkish agreement. He assured that the Egyptian people remained nevertheless opposed to communism and were, more than anyone else, worried over the dangerous pro-communist game now being playing by the military regime, in a desperate and naïve attempt to regain influence in the United States. ${ }^{79}$

Abu al-Fath directly said The United stated government could help that situation either by adopting a hand off policy towards the dictatorial regime or by counseling the resumption of normal and constitutional life in the country. ${ }^{80}$

Abu al-Fath attached to his letter an enclosure in which he tried to prove Nasser as a pro-communism leader to urge the US to realize his danger not only to the old regime in Egypt but also on the US itself.

He mentioned that ex-Judge Ahmed Fuad, Secretary- General of the communist Central Committee in Egypt became Nasser's right-hand man. He was the author of all the bills and leaflets which Nasser had distributed amongst the officers and men of the army and the general population. Another notorious pro-communist, Dr. Rashad al Barraodi, was appointed President of the Board and General Manager of the Industrial Bank, which is sponsored and controlled by the government

The Director of the Regional Office of FAO told the reporting officer in the American embassy some months before that it was common talk in the countryside that the land reform program in Egypt was initiated by the American. ${ }^{81}$ In explanation, the reporting officer pointed out that while the United States was interested in the principle of land reform, it was not advocating any particular plan in any particular country so far as the latter was informed.

In spite of the American support for the land reform, Abu al-Fath tried to focus on what was considered an achievement of the new regime for the people was also directed by the Communism. He said that it was the communists who proposed to Nasser and his colleagues the agrarian reform measure. The communists, however, had an ulterior motive in suggesting the measure: knowing that lack of preparation for such a change must inevitably lead to acute economic disturbance. Those who received grants of land were too poor to exploit it; they could not afford to buy seeds and fertilizers, nor could they pay for irrigation or working equipment. At the same time, the regime had not adequate funds to subsidize the new, small landowners and to enable them to cultivate their holdings.

The communists also correctly estimated the ignorance of the new landowners. when eventually the regime supplied seed and artificial fertilizers, which were to be paid for later from the proceeds of the crops, the poverty-stricken peasants used part of the seed to make bread and sold the rest to buy other foods and supplement their meager diet. The result was that the land was neglected and production fell seriously and naturally most of the peasants were unable to repay the government for the assistance they had received. ${ }^{82}$

About the wide spread influence of the Communism under the new regime Abu al-Fath said that after the compulsory dissolution of political parties and organizations in Egypt, the communists seized the opportunity to try a new means of attracting new adherents to their ranks. They approached the different party leaders suggesting the formation of a National Front to fight the military dictatorship. If this did not succeed with seasoned politicians and Muslim Brotherhood leaders, it made a great impression on the youth of the country, especially college and university students. For the first time in the history of these institutions, several communist candidates were successful in the elections of the student unions. Officially, these unions exist for the purpose of sports and social activities but, in fact, they have always been the political organs if the universities, colleges, and schools. They have in the past played an important role in political movements and their election results have always been regarded as reflecting the opinions of the majority of students on the political situation. ${ }^{83}$

Abu al-Fath talked about the communist figures that used to attack Nasser's regime who in turn arrested and sentenced to varying terms of imprisonment a number of people, mostly political opponents and some communists. Despite these reprisals, the communist activity continued on an undiminished scale. The distribution of bills and leaflets went on, the persons arrested and imprisoned were mostly Nasser's political opponents and the communists among them were of the shop window variety-not the real leaders, who remained protected by anonymity.

The communists took advantage of every event to promote anti-British and anti-American feelings, accusing Nasser of adopting his actions to suit Western policy. They made propagandist capital of the fact that most of Nasser's victims were national leaders, who had played an important role in the Egyptian struggle against Britain. 
It was to be noted that a considerable number of Egyptian communists were able to leave Egypt in spite of the restrictions imposed by the Military regime. These persons had made extensive tours of Europe and the Middle East and contacted other Egyptians who for one reason or another couldn't return to Egypt, with the view of convincing them of the necessity to create a unified front to work against the regime. Wafdists and members of the Muslim Brotherhood who had been so approached have refused any such advantages, preferring to remain clear of communist interference in their efforts to liberate their country from a regime of terror and torture. ${ }^{84}$

It was also to be noted that the communist bulletins were being distributed from Europe especially from Italy to Arab countries. When Nasser quarreled with Iraq the communists, began to court Nasser and entice him to the extreme left. When he clearly expressed a policy in favor of a neutral bloc, well-known communist writers who-had, in the past, refused vast fees for contributions to the junta press, started to publish their propaganda articles in the junta newspapers and magazines. Their aim was to drive the junta regime further and further to the left. Their articles varied in the subject, but not in the spirit. They eulogized the achievements of Red China, as having reclaimed the country from Chaos and abject poverty to conditions of improving prosperity; they praised the Soviet Union and abused America.

Abu al-Fat claimed that any reader of al Gamhouria (the daily organ of the junta regime) would find one or more articles of communist propaganda and would recognize that these were intended to spread communist ideas. Every Tuesday the back page of this newspaper carried a number of articles by famous communist thinkers and propagandists. ${ }^{85}$

Abu al-Fath tried to touch the Wafd problem to gain the US support with it. He said that one of the greatest errors committed by the regime was the dissolution of the political parties and organizations, and the ban on the formation of new ones. The most formidable bulwark against communism in Egypt was formed by the Wafd and the Muslim Brotherhood. At the head of the Wafd were many important landowners and businessmen, whose interest was to combat communism. The Wafd, aware that poverty and the low living standard was a powerful weapon of communist propaganda, was the only party which took steps, when in power, to improve the conditions of the industrial and agricultural labor. Wafd government fixed minimum wages for such labor, encouraged the formation of healthy labor union and organized relations between labor and employers. The inaugurated housing program for the lower salaried workers and introduced a social security system, which included old ages pensions for the poor, and established social centers in groups of villages, having a doctor, nurse, a midwife and an official to guide the fellahins on their different sanitary, social, educational or economic problems. ${ }^{86}$

Finally, he referred that while in the past every Egyptian government forbade the youth of Egypt to participate in the communist sponsored youth congress, Nasser was not only allowing participation, he was also sending, at the expense of the Egyptian government, a large delegation of Journalists, writers, artists, sportsmen, students, etc., numbering 85 persons, presided over by Major Ahmed Shoaieb and Captain Adel Taher. ${ }^{87}$

Through the second enclosure, Abu al-Fath tried to put a spot on the channels where the American economic aids to Egypt were spent. He mentioned that while the people were living in great distress, tens of millions of pounds were being wasted to subsidize either supporters of the regime or a Nazi-like spying network. In a case that came before a military Court on July 4, 1954, one officer revealed that some $£ 17$ million were spent on internal spying services. This lavished spending and corruption had caused two Finance Ministers to resign, fearing the future charges of complicity.

Among the unproductive and extravagant expenditure of the dictatorial regime that he cited were: the maintenance of jails and concentration camps incarcerating some 50.000 political prisoners; the maintenance of the wide intelligence organizations in some neighboring countries; the bribing of various statesmen and politicians in these countries and the financing of subversive activities in unfriendly ones. Substantial sums are also being spent in the Sudan. Millions of pounds are being squandered in Europe by so-called military missions, buying out of date arms and weapons. ${ }^{88}$

Abu al-Fath tried to prove that the military regime was so unpopular and unstable that it had to continue the suppression of all democratic freedoms and fundamental human rights, and to rule through force, violence and terror. Its leaders lived in constant fear for their lives and were daily taking new measures for their personal security. Then he enlisted the measures that had been taken by the Nasser against all of his opponents, intellectuals, education regulations, laws, and the universities immunity and independence.

Abu al-Fath directly talked about what he wanted from the US. He said that America and Britain could help to spare Egypt the disastrous consequences of a brutal and incompetent regime by advising Nasser to lead the country rapidly back to a normal, democratic, constitutional one. The United States should be warned that Nasser's dictatorship commands no support from the people, and that continued support could cause her plans to collapse, in more striking and devastating fashion than the collapse if international policies when the Syrian dictatorship of Colonel Shishakly was thrown out. ${ }^{89}$

Abu al-Fath also tried to warn the US of continuing the same role with Nasser. He said that the recent agitation in certain Arab countries against the Iraqi-Turkish Pact should serve as another warning. Its real cause was not hostility towards Iraq, which was popular among Arab countries for the many services she rendered to Arab and Muslim causes. Nor was it caused 
by real hostility to Turkey. Nasser himself praised it very highly and stressed the secular Turk-Egyptian friendship and the necessity to continue a closer cooperation between both countries. Its real cause was the hostile feeling against America in the Middle East because of her unpopular policies of which Nasser took advantage to incite Arab people against the Pact; and though certain governments wanted to join the pact, they were intimidated by the strong opposition whipped into active demonstrations by past recollections. ${ }^{90}$

Openly Abu al-Fath talked about the other options after Nasser, claiming that chaos and anarchy through the advent of the communists or the Muslim Brotherhood had no real grounds which were viciously entertained by the propagandists of the Junta.

Defending the Muslim Brotherhood, he said Hassan al Hudeibi, the Supreme Guide was naturally opposed to communism and would be prepared, with his organization, to participate actively in the fight against communism. This organization could not be wiped out; its influence, enhanced by its latest persecution, could be made good use of and channeled through social and intellectual activities, from which both the country and the Middle East can positively benefit. ${ }^{91}$

As a way to present the Wafd as a good back up a regime to rule Egypt after Nasser Abu al-Fath said it was Wafd governments that introduced measures to raise the standard of living. This was why it was kept a powerful influence in Egypt. In the past, when Wafd began to lose popular support, it opponents, helped indirectly to revive the Wafd's prestige, and the people found it, by comparison, preferable to all other administrations. ${ }^{92}$

The British were bitter against the Wafd for abrogating the 1936 Treaty an encouraging the Campaign against their troops in the Canal Zone and for other reasons. But they should not forget that the loyal friendship of Nahas Pasha and the Wafd government in 1942 decisively helped to avoid a military calamity for the British in the Middle East. The loyal friendship of the Wafd during the worst period of the war should be remembered.

Abu al-Fath ensured that he received from Nahas Pasha, as well as from all other political leaders inside and from several other prominent personalities, assurances that they no longer think in terms of partisan politics or ambitions. Their only desire was to see Egypt freed from this destructive and tyrannical regime and ensure that a National Union Government lead the country to a normal and democratic life and raise it from the economic and political chaos into which the military Junta had led it, thus restoring stability and regaining some of the lost prosperity, and at the same time establishing friendly and cooperative relations with other Arab countries, and with every country that was working for universal welfare. They were all ready to forget their parties and support a government of National Union, formed by a man such as General Nguib, whose popularity and honestly were beyond any doubt, and who could rally around him all the army and the whole nation. ${ }^{93}$

Abu al-Fath objective now became clear. It was not the matter of replacing Nasser with Naguib, it was just an approach to restore the parliamentary life in Egypt through which the Wafd would return to power. The Wafdists were sure of their popularity and would win in case of free elections were held. Naguib was just an acceptable name to the US as warrantee resuming the republican regime. The Wafd leaders believed that the US unsupportive policy to Farouk would be the same with the Wafd as both failed to achieve the US objectives before the 1952 Revolution. Abu al-Fath wanted to urge the US to move against Nasser whom he presented as suppressive and violently ruling Egypt for their enemies the Communists. He did not deny that the Wafd could loyally cooperate with Britain rather than Nasser's regime.

\section{The Cousin of Fuad Sirag al-Din:}

Fuad Sirag al-Din was arrested in September 1953. His trial became the show trial of the old regime. By the end of the trial Siraj, al-Din had so diverted and diffused the attack that his fifteen-year sentence seemed arbitrary. Though he was only in his mid-forties, Siraj al-Din's career seemed finished. He became a kind of non-person, mentioned in the press only as an epitome of the evils of the old regime. In late 1955 or early 1956, the government quietly released him from jail, but it kept him under house arrest or other restrictions and in 1961 and 1967 it briefly rearrested him. ${ }^{94}$

The US previous reports about Sirag al-Din mentioned that although he was a Pasha and extremely wealthy, being one of the largest landowners in Egypt, had for some time manifested interest in social and labor conditions and had espoused reforms in these fields. Much of Sirag al-Din' strength lies, therefore, in his success in bringing in the workers, socially minded students and other classes to support of the Party. ${ }^{95}$

Following the announcement in December 21, 1954 that the Revolutionary Command Council had undertaken the task of reviewing the general policy of the state with a view to adopting a constitution and establishing a parliament, there was remarkable discussion and comments among Egyptians with regard to the manner, in which the parliament would be set up and the possibility of this taking place by January 1956.

On January 5, 1955, there was a meeting between the Reporting Officer of the American embassy and Fuad Abdel Aziz Sirag al-Din, the cousin of Fuad Sirag al-Din, the Former Secretary General of the Wafd Party. Throughout the 
conversation, Sirag al-Din claimed to be reflecting the ideas of the Wafdist leaders, particular his imprisoned cousin. Abdel Aziz was a lawyer and when the Wafd was in power he was an inspector of the Ministry of Interior.

The American report that was signed by G. Louis James, Charge d'Affaires in Cairo, mentioned that if his remarks truly represented the opinions of the Wafd as he claimed, the Wafdists had altered none of their views concerning the governing of Egypt. They apparently looked upon Egypt as their rightful private domain which had temporarily been seized by upstarts. Their policy was expediency and rule; they viewed that Nasser was considering a return to parliamentary government as an indication of weakness in the regime; and they were optimistic that if a parliament was established, it would eventually fall under their control. ${ }^{96}$

Throughout the conservation Sirag al-Din expressed only the highest regard for Nasser. He said that Nasser was honest, brave and sincere and that he was doing what he thought was best for the future of Egypt. Under certain conditions, he continued, the Wafdists would be willing to cooperate with the regime. Abdel Aziz claimed that leading Wafdists actually encouraged the Free Officers. In fact, Ismail Sirag al-Din, a member of well-known Wafdist Family who was a free Officer now serving as Assistant Military attaché in Paris, acted as a link between the Free Officers and the Wafd before the Coup. He continued, it was planned that the coup would take place in September 1952. Nahas and Fuad Sirag al-Din had gone to Europe for the summer at the request of Hussein Sirry in order to prevent further friction between the Palace and Wafd, but both planned to be in Egypt in September at the time set for the coup. He argued that Ali Maher, Anwar Sadat and Ihsan Abdel Quddos ( editor of the leftist weekly Rose al Youssef) had oriented the regime away from the Wafd with the result that friendly relationship between the Wafd and the Free Officers that both contemplated was never established. ${ }^{97}$

Abdel Aziz claimed also that Nasser himself who was a member of the Wafdist militia in 1935. In addition, prior to the coup, Nasser apparently favored cooperation with the Wafd in achieving his aims. The hopes of the Wafd to cooperate with Nasser were not without reason, he said. The conversation between Wafdists and representatives of the regime revealed that in order to establish a truly popular and stable government, Nasser planned to bring in certain elements from the former political parties who he reestablished a parliament. In a view of this fact, contacts had taken among Wafdists, Saadists, and Liberal Constitutionalists in order to prepare a unified policy for their return to politics. He said that the three parties would unite to form a political alliance, and even if this did not work out, it was certain that the Saadists and Wafdists would be one.

In order to show the continuous influence of Wafd even after the 1952 Revolution, Abdel Aziz explained the family concept that prevailed in the thinking of Egyptians. He said the first question that a salient mainly asked was, what was your family?. Being represented by a member of a respected and powerful family gave an assurance that all Egyptians had traditionally sought. He continued that neither Nasser nor any of the men around him were from the great families and this was the underlying reason for the general sympathy of the people towards the regime. ${ }^{98}$

He then claimed that a certain amount of cooperation between Nasser and the representative of the old parties, based upon the family concept had already taken place. In May 1954 when Nasser intended to establish a National Advisory Council (NAC), he asked the influential families of Egypt to take part. The fact that some of the members of the NAC were to have been appointed because of their relationships was not to be publicized, but the selection of the Council was to have been made partially on this basis because it reflected the realities of politics in Egypt. If the NAC had ever met, it would also have reflected the old political parties in so far as it has always been the influential families that have controlled the parties.

Abdel Aziz stated that Nasser was aware that he had no popular support. But unlike Abu al Fath's demand to depose Nasser, he said that if Nasser intended to remain in power, he had to rely upon the Wafd. An additional difficulty for Nasser was the economic problem. World cotton prices were low and Egyptian cotton had not been selling. The government had done virtually nothing to allocate the problem and the farmer had to unload his cotton before he planted the new crop in March. To a lesser extent, this was also the case with rice crop. The only solution, he said was for the government to buy the crop which meant a financial loss to the government that it could ill afford to bear. In doing this, he commented, the regime would be following the practices for which they jailed Sirag al-Din. ${ }^{99}$

The economic problem, lack of popularity and resulting strain on the RCC, therefore, weakened the regime, and consequently Nasser needed help. The Wafd, he said, was willing to provide Nasser with the means of escape, and in return, it would only ask that he promulgate a constitution and hold parliamentary elections. Whereas the Wafdists would have entered any such arrangement on the conditions set down by Nasser, they had a few conditions if their own which, he maintained, had been communicated to Nasser. First of all, there had to be no procrastination with respect to elections and the return of the parliamentary government. Secondly, neither Gamal Salim, Salah Salim, nor Anwar Sadat had to hold influential jobs were acceptable. ${ }^{100}$

The presence of Nasser and other RCC members in positions of authority would be guarantee to the Free Officers who had become politically involved that no attempts would be made to place them in disadvantageous positions. Abdel Aziz finally 
admitted that the approach of the Wafd was to take every measure considered necessary to separate Nasser from the army after which it would not be so difficult for the representatives of the people rather them the military govern Egypt. ${ }^{101}$

Unlike Abu al-Fath, Abdel Aziz acknowledged that Nasser was the true leader of the Revolution. Naguib he said was opportunist and puppet and with cooperation between Nasser and the Wafd, Naguib would pass into oblivion.

Concerning foreign affairs, he said that the Wafd favored peace with Israel. He unrealistically added that the only condition was for the Israelis to accept the return of the Arab refugees to their homes with minority rights. When he was asked if the Israelis refused to do that, he stated that adequate cooperation by Israel which would be sufficient to permit the refugees to settle elsewhere, such as Sinai, " but we will not accept them in Egypt", he added. To him, the important thing was that in speaking to an American, "the Wafd favored a settlement". ${ }^{102}$

With respect to the Anglo-Egyptian agreement Abdel Aziz was equal as unrealistic from the American view. He described the agreement as being quite great, but that if the Wafd returned to power, it would reopen negotiations in order to modify a few minor points: airbase rights of the British under the agreement, and Egypt's harbors in case of War, and the rights of British troops to re-enter Egypt if there were the danger of a war. He added that there was no doubt that the Wafd favored close relations with the West. ${ }^{103}$

He briefly turned to the Wafd's refusal to accept the Middle East Defense Organization (MEDO) proposal in 1951, claiming that the refusal was the personal act of Mohammad Salah al-Din, the Minister of Foreign Affairs, which neither Nahas nor Sirag al-Din had been previously informed. He expressed a great dislike for Salah al-Din.

At several points throughout his discourse he mentioned that most Egyptians depended upon the United States as being fully committed to a policy of supporting Nasser's dictatorial regime against the Egyptian people and that considerable hope prevailed that the United States would modify its policy enough to show the Egyptian people that in the future this would not be the same. ${ }^{104}$

According to the American report, In spite of his talk about the people and democracy, there was little doubt that his thinking was geared only to return of the Wafd to power for its own benefit by means of any expediency. At one point he even said that only one party was necessary for Egypt; that party being the Wafd. If Nasser accepted the Wafd, political groups rather than Wafd were not necessary.

Concerning "one party thinking", he attached dictatorship. Although he made complimentary remarks about Nasser, he also said that the regime was an intolerable dictatorship. In presenting this opinion, he said that the regime was operating to the advantages of communism because power had become extremely centralized and the number of objectives that communists would have to control in assuring power had become minimized.

While he said the Wafd accepted the reforms of the institutions, he said land reform had been hard for Egypt because the landowners had not been compensated. Abdel-Aziz confirmed the lands distributed by the government to farmer land holders was worthless, and because of the land program, many of the farmer large landowners had given up their interest in farming and moved into urban as a result, rural economy of Egypt was distrust grating. He also mentioned the High dam as an unusual project. As an alternative, he suggested improving the present rural means of Egypt and introducing light rural industry. ${ }^{105}$

For the US, while he spoke in favor of democracy, Abdel Aziz denied practical democracy when he said that the Wafd could represent the people and those other political groups had no place in the Egyptian politics. His remarks concerning the great families only confirmed his denial of the democracy which he advocated. Another inclination of his attitude on the subject was that although he spoke at length about the problems of the rural Egyptians, he only dealt with the great landowners and did not mention the agricultural measures. His entire attitude was the essence of political cynicism. ${ }^{106}$

On February 9 and 16, Abdel Aziz again contacted the American Embassy in Cairo. He told W. R. Brown that The Wafd was fully aware that Nasser was in no position to hold elections in 1956 as he had promised. He stated that Nasser would not be able to fulfill his promise because his supporters, the Free Officers, were against elections and because in free elections the members of the RCC would certainly be defeated. Abdel Aziz continued that in recent conversation Major Ahmed Amar, Director of the Military Office, had conceded to him that the regime could not win an election by the margin required to govern the country unless the ballot boxes were stuffed at the Ministry of Interior. ${ }^{107}$

Abdel Aziz clarified that the Wafd's only activity would be to keep Nasser's promise before the people, and to put enough pressure on Nasser to force him into holding elections. Abdel Aziz expressed complete confidence that in anything approaching a free elections the Wafd would be certain to win. He said that the civil servants, the fellahin, and the urban middle class would vote against the regime and their support would be sufficient to assure a victory for the Wafd. 
He said if single party elections were held, the Wafd would work actively to keep the people away from the polls, and demonstrations protesting against this undemocratic practice would be encouraged. Without explanation, he commented that the actions of the police force at the time of elections would be a big surprise to the regime because "the police will assure a Wafdist victory". ${ }^{108}$

He placed considerable importance upon the influence that large Wafdist families such as his own and the Badrawi's would have on the outcome of the elections in rural areas. He said that these families were the embodiment of the Wafd, and even though the regime had limited their land holdings with the land reform program, it had not broken their power. To demonstrate the inability of the regime to completely strip these families of their power, he told of an example in which the regime recently selected as a village Omdah an individual who it was believed would assure that anti-regime elements would have no influence in the village. The government elected a person who was the Brother of a woman married to Sirag al-Din. When the Wafd decided to become active, it would be upon the persons that it would rely on. ${ }^{109}$

It was Nasser's promise of elections that caused the Wafd to take a passive role the March 1954 crisis, he stated but the Wafd will not be thickened by such promises again, and the former leaders have already considered various means of instigating a crisis if the regime does not fulfill its promise.

Abdel Aziz clarified that one means would be to present to Nasser a public petition demanding free elections. He said that at the proper time copies of the petition would be widely circulated; therefore, it would be impossible for the regime to keep its existence a secret. This petition would bear the names of all former political leaders, even those who have been on relatively friendly terms with the regime. As a safeguard, copies of the petition would be sent to all major embassies and all foreign newsmen; therefore, if the regime contemplated taking action against any of the petitioners, it would find itself in the distasteful position of knowing that the news would be spread abroad that they were punished for only demanding the return of democratic institutions. ${ }^{110}$

He further calculated that overt action by the Wafd would instigate disagreement among RCC members and would thereby weaken the structure of the military regime sufficiently to permit free elections to be held and the Wafd, by winning the elections, to subsequently resume its "rightful" position of guiding Egyptian political affairs. He concluded that if the United States simply advocated "freedom and democracy" it would have an adverse effect on Nasser's regime. ${ }^{111}$

The American report criticized Abdel Aziz Sirag al-Din and the Wafd's attitude in general. It mentioned that his thinking was based entirely on the belief that the Wafdists were the rightful rulers of Egypt. If his statements accurately reflected Wafdist thinking, they indicated that the Wafdists considered the Egyptian political scene unchanged since they were last in power. This apparently led them to the belief that their party machinery could spring to life overnight and successfully would deliver them a parliamentary victory, particularly in the rural areas.

It appeared that the Wafd had correctly observed that a great deal of apathy for the revolution existed among the people, but if the Wafd thought that it would be given an opportunity to convert this apathy into active opposition to the regime, it was, without a doubt, underestimating the ability of the regime. ${ }^{112}$

The ability of the Wafd to create pressure on the Nasser's government to precipitate any kind of a crisis, was questionable, since 1952 the Wafd had done nothing to threaten the existence of the regime, and in spite of the fact that Wafdists reportedly had set themselves a deadline of January 1956, so long as they were not committed in any way to take overt action they could easily beg off when the time came. If any domestic political disturbances occur in Egypt, it was doubtful if the Wafd would ever be the focal point of the opposition that caused them. A correct assessment of the Wafd's position would seem to be that it would continue to wait hopefully, but inactively and to think of the day when it could be profit from internal dissensions within the regime.

The most revealing thing about the remarks of Fuad Abdel Aziz was that he constantly spoke of the Wafd regaining power, but he never mentioned what the Wafd hoped to do for Egypt except to control it. ${ }^{113}$

In spite of the US- Egypt tense relations in 1955, both approaches of Abu al-Fath and Abdel Aziz Sirag al-Din did not convince the US to move against Nasser. In contrary, the upcoming events went for Nasser's side.

\section{King Farouk after the Tripartite Aggression:}

On October 31, British and French with Israel planes started bombing Egypt. Stadiem claimed that at the height of the Suez Crisis, Farouk sent a confidential message to Eden, Eisenhower and President Coty of France, while Clair McBride claimed that soon after the Suez Crisis Farouk sent this confidential message. Both cited a message that was literally misinterpreted. They did not mention that this confidential message was in French then the Department of State translated it into English. They focused on the signature of Farouk as Farouk of Egypt. ${ }^{114}$ Latifa Salim claimed that Farouk attacked Nasser in this message asking the leaders of the three countries to save Egypt. ${ }^{115}$ 
In fact, Farouk, according to the US Department of State Documents, signed this confidential letter on September 19, and it was written in French but was sent to the American embassy in Rome on September 25. The letter of King was:

"Mr. President,

When we were forced to leave our country under circumstances well known to all and which motivated our departure, we preferred to submit to the lot which fate reserved for us rather than encourage and support, by bellicose attitude, those numerous elements still devoted to us, thus suppressing risk of an outbreak of fratricidal war.

We did that only to avoid spilling the precious blood of our dear subjects through the manifestation of force, however, legitimate.

Since then, never having lost sight of supreme interest of our dear country, we have followed and observed with close attention development of subsequent events.

Without wishing open polemic and judge policy which is beyond our control, we must note, alas, that at the opportune moment we predicted and foresaw precisely the unhappy unfolding of most of these events.

The disastrous situation in Egypt, although we remain silent, touches our heart more than any other, and seeing perilous way which has been followed we take this moment to raise our voice and ask you, knowing profoundly human qualities your nation and yourself, to try all means in your power to bring pacific solution to those problems that divide your government from that of a people which cannot in all justice be held responsible for its acts and pay with its blood for errors committed.

May God help us in this prayer, convinced that voice of reason and of the heart will keep from our dear people, whom we love, as well as from humanity, the horrors of a conflict which who are sure is still largely available.

May peace and Mercy be with us.

Farouk R. (Rome)."116

In response, the Department of State in Washington sent, on September 27, to the American embassy in Rome that it was recommended to inform the Ex-king's representative the following, to be conveyed to Farouk. "The Department of State desires to give assurances of the continuing determination of the United States Government to seek a peaceful solution of the Suez Canal". ${ }^{117}$

King Farouk did not attack Nasser directly but mentioned that he predicted these events. It was clear from the letter that his supreme interest was his county, Egypt. Before, orally Farouk described the new regime as gangsters, and it was normal to bear them the responsibility of this invasion after 4 years of his deposition. King Farouk might expect it to be the end of Nasser, but surely did not expect that the American support to Nasser and its dream to replace Britain in the Middle East would force the Tripartite invading countries to withdraw; and Nasser would come to an even bigger national hero for finally vanquishing the long despised British and driving them out of Egypt, a feat which no one from Mohamed Ali to Farouk could ever accomplish. This was perhaps his last evidence of the serious interest in Egypt. From 1956 Farouk's life became a social round of the international circuit, Geneva, Cannes, Rome; he was granted citizenship of Monaco

\section{The Wafd after the Tripartite Aggression:}

The Political triumph of Nasser after the Tripartite Aggression ended also the dreams of Wafd party to return the political scene. No serious direct contact between the Wafd and the US occurred after 1956, except another letter was sent from Mahmoud Abu al-Fath to the American President in 1957. Although his first letter was left unanswered as he himself mentioned; on the contrary, the US and its allies gave Nasser every possible help to remove General Naguib and moderate, liberal military and civilian elements in the country and impose and foster his regime in spite of its black record of violence and corruption, ${ }^{118}$ but the new escalated incidents in the Arab region urged him to re-write to the US President.

The American support ended a military coup against King Hussein of Jordan in spring of 1957. This American reaction revived the hopes of Abu al-Fath to have the same reaction in Egypt to suppress the military regime and return the monarchy one. For Abu al-Fath, although the US supported Nasser in the Suez Crisis 1956, but it got rid of the Nasserist Nabulsi government in Jordan and continued its unsupportive economic policy with Nasser in 1957.

He started his letter expressing on behalf of the Egyptian and Arab people to the American President their deep feeling of gratitude to the US for the support it gave Jordan and its King which, no doubt, was the decisive factor in that crisis.

Abu al-Fath wanted to seize the chance of Nasser's unfaithful policy towards the US after its support during the Suez Crisis, to agitate its suspicion towards Soviet influence on Nasser. He said that Apparently the Department of State believed that Nasser was not really a pro-communist and that there was hope to detach him from the Soviet orbit and that the anticommunist measures of King Hussein were taken with Nasser's support, approval and blessing. 
Abu al-Fath wanted to approve his views saying that When 17 communists were brought before a court-martial only the three least dangerous were sentences and the fourteen most active, amongst whom was the secretary of the Party, were acquitted and released to resume their subversive work.

When a young man, Mustafa Mahmoud, printed a book, "the God and the Man", which preached atheism, denied the existence of God, ridicules the apostles and prophets, and denounces all religious, Islam, Christianity and Judaism, and thus committed a crime severely punished under existing laws it was this same special office that instructed the AttorneyGeneral not to prosecute the author and publishers under the pretext of the freedom of Ideas and indefinitely prolong the enquiry. This freedom was only allowed for communist books and publications. ${ }^{19}$

The way America reacted to the Jordan conspiracy, the way it rapidly dispatched its formidable Sixth Fleet to the Easter Mediterranean with loud, specific and clear warnings, further convicted the Russians that Nasser's deceit methods were most appropriate and they inspired stooges in Egypt and Syria to multiply affirmations of non-communism. ${ }^{120}$

From reliable sources close to Nasser, Abu al-Fath knew that the Russians directed Nasser and the Syrian rulers to try to patch up differences with Britain and France and resume normal relations with them. He claimed that Nasser, immediately sent to Switzerland Mr. Kamal Abdel Nabi his Former Ambassador in Paris with a few assistants and colonel Sarwat Okasha Former Military Attaché there to discreetly try conciliation with the French. Other delegates were sent and are presently visiting France or on their way to it one composed of Dr. Ahmed Selim Secretary to the Production Board, and two other members who were going to discuss the execution of the first part of the High Dam Project by French companies and French credits. Others were negotiating the sale of cotton etc...By this policy the Russians also seek to detach Britain and France from America, seizing the opportunity of their bitter disappointment with the US Suez policy.

All the key posts were in the hands of fanatic communists. The Chief of the Egyptian Police Force was supposed to combat communism was well known convinced communist and was forming communist cells amongst the officers and men under his order. The man who controlled the stage and mass education was a well-known communist. Ahmed Hamroush was well-known to the American Embassy. Three or four years ago the USA government invited the newly graduated staff officers to visit America but when the names were communicated to the American Embassy Ahmed Hamroush was refused to be a reputed communist and he was only accepted after insistence and pressure. ${ }^{121}$

The Russians and Nasser did not admit defeat in Jordan and were continuing their intrigues against King Hussein by creating trouble again and get rid of the King and his supporters. They were continuing the Jordan battle on Lebanese territory. But the Lebanese President, Camille Chamoun resisted Nasser's most unscrupulous campaign of corruption, subversion, intimidation, and vilification to which other heads of Arabs States and politicians had succumbed at one or the other.

He claimed that plots by Nasser's military attaché were discovered in several other countries beside Lebanon, Jordan, Saudi Arabia, Iraq, Lybia, Sudan, and Ethiopia, not to mention serious intrigues in Morocco and Tunisia. Even Sweden had to expel the Egyptian Military Attaché. ${ }^{122}$

Abu al-Fath attacked the US saying that the American attitude during the Suez Crisis was purposely misrepresented and extensively exploited by Nasser to give him a big build-up and represent him as a great Arab hero greater than Saladin, that encouraged him to seize power, establish his authority and impose his regime on an unwilling people

By the end of his letter, Abu al-Fath clearly asked the US to continue its economic besiege against Nasser. He asked the President if for any reason the American government preferred to go on with its long-term methods expect that it would refrain from giving Nasser any financial or economic help.

He referred that Nasser's regime was completely bankrupt and shortly would be unable to pay salaries. It had been living on expediency amongst which was the printing of bank-note of small values (less than one pound) which did not come under the control of the National Bank of Egypt. He had notes to the amount of about one hundred million pounds printed and couldn't do this anymore. He couldn't pay salaries or large credits in notes of one half or quarter of pound notes. By high officials of the Ministry of Finance, Abu al-Fath knew that if Nasser didn't get outside help he would shortly be unable to pay government officials' salaries, and Nasser depended on Hare, the American Ambassador to Egypt, to negotiate aid. ${ }^{123}$

Al-Fath did not realize the fact that King Hussein of Jordan was not like King Farouk of Egypt for the US. Hussein was the permanent ally to the US in the Middle East. He did not refuse a peace treaty with Israel, but the problem was in Egypt. Farouk left no hope for the US to achieve their objective in the Middle East with his existence that was the reason for the US to support the new military regime in Egypt. The economic pressure on Nasser was President Eisenhower and his Secretary of State Dulles's policy. They preferred it rather than any military intervention. But soon the US's plans of economic and financial besiege would prove to be useless with Nasser, that would later during the 60s give the green light for a military move against Egypt. 


\section{Conclusion:}

King Farouk and the Wafd party were the main figures of the monarchy regime of Egypt. After the 1952 Revolution, Farouk was forced to leave Egypt and the Party of the popularity was dissolved like the other political parties in 1953. The United States as a Superpower in the Middle East played a deceive role in the success of the 1952 Revolution. Both, Wafd and King Farouk, used the year 1955 that marked the tense relation between Nasser and the US, to contact the US but from different perspectives. Unlike the previous references that referred the first contact was in 1956, the research approved that the first documented contact between King Farouk and the American embassy in Rome was in 1955. During his conversation, Farouk described the new officers as gangsters. He frankly blamed the US and the West for the deteriorated situation in the Middle East. He assured that his meeting with the American President Roosevelt in 1945, and their conflict over the Jewish state in Palestine, was the origin of the American role to depose Farouk from Egypt in 1952.

Farouk kept silent and did not show up until a month before the Suez Crisis, in September 1956 he sent a confidential letter, in French, to the American President Eisenhower asking him to intervene with pacific solutions to solve the problem. Farouk did not attack Nasser or his regime; he just mentioned that these incidents were predicted. That letter was the second and the last time to contact the US till Farouk's death in 1965.

The Wafd party after the 1952 Revolution, whose leaders were either in prison or under house arrest, did not lose their hope to return to power under the new regime. Abdel Aziz, Cousin of Fuad Sirag al-Din contacted the US twice in 1955, while Mahmoud Abu al-Fath contacted the US once in 1955 and the second time in 1957.

Both approaches presented the unplanned policy of the Wafd towards the US. They were keen to gain the US support against Nasser but from different perspectives. Abdel Aziz Sirag al Din, who talked on behalf of the Wafdists, tried to prove that Nasser's regime did not achieve any popularity among the Egyptians. In spite of the land reform and the big landlords' loses of properties, their influence was still strong in the rural areas. He tried to convince the US to urge Nasser to hold free parliamentary elections by 1956; because the Wafd leaders were sure that if there were a free election, they would win. He acknowledged that Nasser was the true leader of the Revolution. To encourage the US to go behind the Wafd's return, Abdel Aziz assured that any of the Wafd's foreign policy concerning Israel, Britain, or the MEDO could be revised in case they returned to the political scene.

The US criticized the Wafd approach mentioning that their thinking was based entirely on the belief that the Wafdists were the rightful rulers of Egypt. The US saw that the most revealing thing about the remarks of Fuad Abdel Aziz was that he constantly spoke of the Wafd regaining power, but he never mentioned what the Wafd hoped to do for Egypt except to control it.

Unlike Abdel Aziz Sirag al-Din, Mahmoud Abu al-Fath, who was the owner of the pro-Wafd newspaper al Misri, in his letters to the American President, he attacked Nasser and tried to approve that he was pro-communism. He criticized his submissive policy and talked about getting rid of him. He frankly presented the alternative options after Nasser. He talked about Naghuib as a ruler of Egypt with the Wafd who did many achievements to raise the standard of living to the Egyptians and still their popular party.

In his second letter in 1957, Abu al-Fath wanted the US to follow the same policy that it followed against the military coup in Jordan to support King Hussein in 1957. This time, he urged the US to continue its economic pressure on Nasser in order not be able to pay the government officials' salaries that alarmed with public storm against Nasser's regime.

Although both King Farouk and Wafd did not affect the US policy towards Nasser, it reflected the deep difference between King Farouk and the Wafd. With their contacts with the US, Farouk's supreme interest was Egypt, while Wafd' was their return to authority even if it needed to change their principles.

Abu al-Fath as intellectual found out that the way to urge the US to move against Nasser was to feel threat upon its interest. The US was sure from its early reports about Nasser that Communism did not have an influence upon him; that was the reason for the ignoring the Abu al Fath's claims. The other claims of Abu al-Fath and Abdel Aziz did not re-shape the US' foreign policy towards Nasser; the US' interest in Egypt and the Middle East were the only decisive point in this in the US's foreign policy. 


\section{References:}

${ }^{1}$ Muhammad Abdel-Wahab S. Ahmed, Nasser and American Foreign Policy 1952-1956, (Cairo: AUC press, 1989$), 51$.

${ }^{2}$ M. A.Wahab S, Ahmed, Nasser and American Foreign Policy, 52.

${ }^{3}$ M . A.Wahab S, Ahmed, Nasser and American Foreign Policy, 58.

${ }_{5}^{4}$ Jon B. Alterman, Egypt and American Foreign Assistance, 1952-1956, (New York: Palgrave Macmillan, 2002$), 3$.

${ }^{5}$ Joel Jordon, Nasser's Blessed Movement Egypt's Free Officers and the July Revolution, (New York: Oxford University Press, 1992 ), 13

${ }^{6}$ William Stadiem, Too Rich; the High Life and Tragic Death of King Farouk, (New York: Carroll and Graf Publishers, 1991), 347. I Barrie St. Clair McBride, Farouk of Egypt, ( New York: A.S.Barnes, 1968), 218. / Latifa M. Salim, Farouk min al -Milad ela al-Rahil, ( Farouk from Birth to Departure), (Cairo, Dar al-Shuruq, 2005), 835-836.

${ }^{7}$ The US Department of State, weekly summary of Events, Egypt and the Sudan- July 22-23, 1952, .July 28, 1952, Central Files, Box

3951, Egypt 1950-1954, Internal Affairs, Reel 2,2.

${ }^{8}$ M. A.Wahab S, Ahmed, Nasser and American Foreign Policy, 54.

${ }^{9}$ M. A.Wahab S, Ahmed, Nasser and American Foreign Policy, 55.

${ }^{10}$ Michael T. Thornhill, " Britain, the United States and the Rise of an Egyptian Leader: The Politics and Diplomacy of Nasser's Consolidation of Power, 1952-4”, The English Historical Review, Vol. 119, No. 483 (Sep., 2004), 898

${ }^{11}$ The US Department of State, Israel Views on Egyptian Situation, July 31, 1952, Central Files, Box 3951, Egypt 1950-1954, Internal Affairs, Reel 2, 3.

12 The US Department of State, Israel Views on Egyptian Situation, 4.

${ }^{13}$ The US Department of State, Israel Views on Egyptian Situation, 5.

${ }^{14}$ Joel Jordon, Nasser's Blessed Movement Egypt's Free Officers and the July Revolution, 71.

${ }^{15}$ Michael T. Thornhill, "Britain, the United States and the Rise of an Egyptian Leader", 900-902.

${ }^{16}$ Joel Jordon, Nasser's Blessed Movement Egypt's Free Officers and the July Revolution, 73

17 The US Department of State, Egypt's New Era- the First Three Weeks, .July 30, 1952, Central Files, Box 3951, Egypt 1950-1954, Internal Affairs, Reel 2, 2

${ }^{18}$ Michael T. Thornhill, “Britain, the United States and the Rise of an Egyptian Leader”, 902.

${ }^{19}$ Joel Jordon, Nasser's Blessed Movement Egypt's Free Officers and the July Revolution, 73-74

${ }^{20}$ Joel Jordon, Nasser's Blessed Movement Egypt's Free Officers and the July Revolution, 74.

${ }^{21}$ Michael T. Thornhill, "Britain, the United States and the Rise of an Egyptian Leader", 903-904.

${ }^{22}$ T. R. L., "Egypt since the Coup d'états of 1952", The World Today, Vol. 10, No. 4 ( 1954), 142

${ }^{23}$ The US Department of State, Egypt's New Era- the First Three Weeks, July 30, 1952, 3.

${ }^{24}$ The US Department of State, Egypt's New Era- the First Three Weeks, 3-.4

${ }^{25}$ Ali Maher was the Prime Minister for the First time in 1936 for less than 4 months, then he became a Prime Minister for the second time from August 18, 1939 until June 1940, then he resigned because of British pressure. From 1945 until his appointment as Prime Minister on January 27, 1952, Maher acted as a member of the Council of Fuad I university, as a member of the State Economic Council, and as a Director of the Credit Frontier Egyptian, of which he eventually became Manager. He has been senator for many years. Ali Maher's appointment as Prime Minister was announced on the evening of January 27, 1952, after the King had dismissed the Nahas Pasha government for failing to maintain public order. The King's selection of Maher to head the new government was attributed to the latter's pro-palace record, the fact that he was on good terms with all the party leaders, was known as strong man, was a close friend of Fafiz Afifi Pasha, chief of the Royal Cabinet, and because he had at least the reputation of being anti- British. He has launched on a program of creating a national Front with representation from widely divergent groups as the Wafd, the Saadists and even the Muslim Brotherhood.

The US Department of State, Confidential Biographical Information about Ali Mher Pasha, February 9, 1952, Central Files, Box 3951, Egypt 1949-1954, Internal Affairs, Reel 11, 1-4.

26 Joel Jordon, Nasser's Blessed Movement Egypt's Free Officers and the July Revolution, 72.

27 The US Department of State, Egypt's New Era- the First Three Weeks, .July 30, 1952, 6.

${ }^{28}$ The US Department of State, Egypt's New Era-the First Three Weeks, .July 30, 1952, 6.

${ }^{29}$ Michael T. Thornhill, "Britain, the United States and the Rise of an Egyptian Leader", 900-901

${ }^{30}$ The US Department of State, Egypt's New Era- the First Three Weeks, .July 30,1952, 7.

${ }^{31}$ The US Department of State, Egypt's New Era- the First Three Weeks, .July 30, 1952, 7.

${ }^{32}$ The US Department of State, Egypt's New Era- the First Three Weeks, .July 30, 1952, 8.

${ }^{33}$ The US Department of State, Egypt's New Era-the First Three Weeks, .July 30, 1952, 9.

${ }^{34}$ The US Department of State, Israel Views on Egyptian Situation, July 31, 1952, 2

${ }^{35}$ The US Department of State, Israel Views on Egyptian Situation, .July 31, 1952, 3

${ }^{36}$ The US Department of State, Israel Views on Egyptian Situation, .July 31, 1952, 4.

${ }^{37}$ Letter from President Eisenhower to General Mohamed Naguib to the March 24, 1953, 4P, Security Declassified. Eisenhower Library, papers as president of the United States 1953- 1961, White House, confidential, 3.

${ }^{38}$ Letter from General Mohamed Naguib to the President Eisenhower April 22, 1953, 4P, Security Declassified. Eisenhower Library, papers as president of the United States 1953-1961, White House, confidential, 1-2.

${ }^{39}$ Joel Jordon, Nasser's Blessed Movement Egypt's Free Officers and the July Revolution, 75

${ }^{40}$ Robert Stephens, Nasser: a Political Biography, ( New York: Simon and Schuster), 1971, 123-124.

${ }^{4141}$ Robert Stephens, Nasser: a Political Biography, 125.

${ }^{42}$ Robert Stephens, Nasser: a Political Biography, 125. 
${ }^{43}$ T. R. L., "Change of Leadership in Egypt", The World Today, Vol. 11, No. 2 (Feb., 1955), 52

44 The US Department of State, Egyptian Internal Situation Unsettled, March 25, 1954, Central Files, Box 3951, Egypt 1949-1955, External Affairs, Reel 4,1.

${ }^{45}$ The US Department of State, Wafdists and Muslim Brotherhood Declares their Stand Concerning Current Political Situation , March 25, 1954, Central Files, Box 3951, Egypt 1949-1955, External Affairs, Reel 4,1-2.

${ }^{46}$ Robert Stephens, Nasser: a Political Biography, 128. .

${ }^{47}$ T. R. L., "Change of Leadership in Egypt", 54.

${ }^{48}$ Charles Edward Zimmer, "United States Foreign Policy towards Egypt 1955-1958”, ( Master diss...,American University in Beirut, 1962), 17-24

${ }^{49}$ Charles Edward Zimmer, "United States Foreign Policy towards Egypt 1955-1958”, 25-29.

${ }^{50}$ Peter L. Hahn, "National Security Concerns in US Policy Towards Egypt, 1949-1956", in the Middle East and The United States, a Historical and Political Assessment, ed. Lesch, Davis W (Boulder, Colo.: West view press, 2007), 80.

${ }^{51}$ Muhammad H Haykal, Malafat Al-Suwaiys, (The Files of the Suez), (Cairo: Al-Ahram, 1996), 368.

${ }^{52}$ The US Department of State, Discussion of Egyptian Foreign policy by Minister of Interior Zacharia Muhieddin, June 21, 1955, Central Files, Box 3953, Egypt 1955-1959, Internal Affairs, Reel 1, 2-3

${ }^{53}$ The US Department of State, The State of Egypt's Foreign Relations as Prime Minister Nasser sees it, , June 23, 1955, Central Files, Box 3953, Egypt 1955-1959, Internal Affairs, Reel 1,1.

${ }^{54}$ The US Department of State, Conversation with Nasser on August 8, 1955 , August 11, 1955, Central Files, Box 3953, Egypt 19551959, Internal Affairs, Reel 6,4.

55 The US Department of State, Farouk, the US and the Egyptian Crisis, report prepared by Mr. Broune from NE to Mr. Jones in the Department of State, July, 30, 1952, Central Files, Box 3951, Egypt 1950-1954, Internal Affairs, Reel 2,1-2-3.

56 The US Department of State, a letter sent from Louis Troy, chairman of the Troy World Communication(1173Hayes street, San Francisco 17, Calif, USA) to John Foster Dulles, Secretary of State, March 4, 1955, Central Files, Box 3953, Egypt 1955-1959, Internal Affairs, Reel 3,3.

57 The US Department of State, Memorandum of conversation with Ex-King Farouk, From American Embassy in Rome, signed by Francis T. Williamson, Counselor of Embassy, November 8, 1955, Central Files, Box 3952, Egypt 1955-1959, Internal Affairs, Reel 3,1

${ }^{58}$ The US Department of State, Memorandum of conversation with Ex-King Farouk, From American Embassy in Rome, 2-3-4.

${ }^{59}$ M. A.Wahab S, Ahmed, Nasser and American Foreign Policy 57.

${ }^{60}$ M. A.Wahab S, Ahmed, Nasser and American Foreign Policy 58.

${ }^{61}$ M. A.Wahab S, Ahmed, Nasser and American Foreign Policy 59.

${ }^{62}$ Michael T. Thornhill, “Britain, the United States and the Rise of an Egyptian Leader:”, 899.

${ }^{63}$ A maverick of humble origins who established a construction firm in the early 1920s and built it into the most successful business group of the era. By the 1940s Abbud controlled the Sugar Company, the Khedival Mail Line, and the Egyptian General Omnibus Company, He was also the largest shareholder of Bank Misr and battled his way to a seat on the board of directors in 1950. In the same year he also became the first Egyptian to serve as a director of the Suez Canal Company.

Joel Beinin, "Egypt: society and economy, 1923-1952" in M.W. Daly(ed), Cambridge History of Egypt, Part II,(London: Cambridge University Press, 1998), 326.

${ }^{64}$ The US Department of State, Ahmed Abboud Pasha Comments Regarding the Egyptian-Iraq Tension, March 14, 1955, Central Files, Box 3953, Egypt 1955-1959, Internal Affairs, Reel 6, 1.

${ }^{65}$ The US Department of State, Regime still undecided on Future Form of Government, April 7, 1955, Central Files, Box 3952, Egypt 1955-1959, Internal Affairs, Reel 1, 1

${ }^{66}$ The US Department of State, Regime still undecided on Future Form of Government , 2

${ }^{67}$ The US Department of State, Regime still undecided on Future Form of Government, 2.

${ }^{68}$ The US Department of State, Regime still undecided on Future Form of Government , 3.

${ }^{69}$ The US Department of State, Regime still undecided on Future Form of Government 4.

${ }^{70}$ The US Department of State, Regime still undecided on Future Form of Government, 4

${ }^{71}$ The US Department of State, Regime still undecided on Future Form of Government, 5.

72 The first issue of al Misri was issued on October 11, 1936. It was daily newspaper competitor to al Ahram.

${ }^{73}$ Suhair Iskander Ragheb, "Mawqif Garidat al- Misri min al-Qadaiya al-Wataniyah" (the Newspaper al-Misri's Attitude towards the National Cause 1936-1946), (Master diss., Cairo University, 1982),70-75.

${ }^{74}$ The US Department of State, Reported Peace Offer Which Was Rejected by Mahmoud Abul Fath, October 16, 1956, Report signed by W.H. Weathersby, Public Affairs Officer in the American embassy in Egypt, Central Files, Box 3952, Egypt 1955-1959, Internal Affairs, Reel $1,1$.

${ }^{75}$ Abdel Rahman al-Refie, Thawret 23 Yulu 1952: Tarikhona al Qawmi fi Saba' Sanawat 1952-1959 ( 23 July 1952 Revolution: our National History in Seven Years 1952-1959), ( Cairo, Dar al-Maaref, 1989), 121-124

${ }^{76}$ The US Department of State, Confidential Biographic Data-Ahmed Abul Fath, February 18, 1952, Central Files, Box 3951, Egypt 1949-1954, Internal Affairs, Reel 1, 2.

${ }^{77}$ The US Department of State, a Letter from Mahmoud Abu al Fath sent from al Misri Bureau to American President Eisenhower , July 5, 1955, Central Files, Box 3952, Egypt 1955-1959, Internal Affairs, Reel 2, 1.

${ }^{78}$ The US Department of State, a Letter from Mahmoud Abu al Fath sent from al Misri, 1.

${ }^{79}$ The US Department of State, a Letter from Mahmoud Abu al Fath, 3.

${ }^{80}$ The US Department of State, a Letter from Mahmoud Abu al Fath,4. 
${ }^{81}$ The US Department of State, an Appraisal of Egypt's Land Reform Development in 1953, January 9, 1954, Central Files, Box 3951, Egypt 1949-1955, External Affairs, Reel 22,1.

${ }^{82}$ The US Department of State, a Letter from Mahmoud Abu al Fath, enclosure 1, 1.

${ }^{83}$ The US Department of State, a Letter from Mahmoud Abu al Fath, Enclosure 1, 3.

${ }^{84}$ The US Department of State, a Letter from Mahmoud Abu al Fath, Enclosure 1, 5.

${ }^{85}$ The US Department of State, a Letter from Mahmoud Abu al Fath, 6.

${ }^{86}$ The US Department of State, a Letter from Mahmoud Abu al Fath, 7.

${ }^{87}$ The US Department of State, a Letter from Mahmoud Abu al Fath, 7

${ }^{88}$ The US Department of State, a Letter from Mahmoud Abu al Fath, enclosure 2, 7.

${ }^{89}$ The US Department of State, a Letter from Mahmoud Abu al Fath, enclosure 2, 8

${ }^{90}$ The US Department of State, a Letter from Mahmoud Abu al Fath, enclosure 2, 9.

${ }^{91}$ The US Department of State, a Letter from Mahmoud Abu al Fath, enclosure 2, 10.

92 The US Department of State, a Letter from Mahmoud Abu al Fath sent from al Misri Bureau to American President Eisenhower, 11.

${ }^{93}$ The US Department of State, a Letter from Mahmoud Abu al Fath sent from al Misri Bureau to American President Eisenhower, 12.

94 Donald M. Reid, "Fu'ad Siraj al-Din and the Egyptian Wafd", Journal of Contemporary History, Vol. 15, No. 4 (Oct., 1980), $722-724$.

${ }^{95}$ The US Department of State, Election of Fuad Serageddin as Secretary General of the Wafd Party Following the Resignation of Abdul Salam Gomaa Pasha, June 28, 1948, Central Files, Box 3950, Egypt 1945-1949, Internal Affairs, Reel 2, 2.

${ }^{96}$ The US Department of State, the Visit of the Wafd, January 12, 1955, Central Files, Box 3952, Egypt 1954-1959, Internal Affairs, Reel 2,1 .

${ }^{97}$ The US Department of State, the visit of the Wafd, 1

${ }^{98}$ The US Department of State, the visit of the Wafd, 2.

99 The US Department of State, the visit of the Wafd, 3

100 The US Department of State, the visit of the Wafd, 3.

${ }^{101}$ The US Department of State, the visit of the Wafd, 3.

${ }^{102}$ The US Department of State, the visit of the Wafd, 4.

${ }^{103}$ The US Department of State, the visit of the Wafd, 4.

${ }^{104}$ The US Department of State, the visit of the Wafd, 4.

105 The US Department of State, the visit of the Wafd, 5.

${ }^{106}$ The US Department of State, the visit of the Wafd, 6.

${ }^{107}$ The US Department of State, The Wafd looks Forwards to 1956, February 17, 1955, Central Files, Box 3952, Egypt 1955-1959, Internal Affairs, Reel 1, 1

108 The US Department of State, The Wafd looks Forwards to 1956, 2

109 The US Department of State, The Wafd looks Forwards to 1956, 2.

${ }^{110}$ The US Department of State, The Wafd looks Forwards to 1956, 3.

${ }^{111}$ The US Department of State, The Wafd looks Forwards to 1956, 4.

112 The US Department of State, The Wafd looks Forwards to 1956, 5.

${ }^{113}$ The US Department of State, The Wafd looks Forwards to 1956, 5.

${ }^{114}$ William Stadiem, Too Rich; the High Life and Tragic Death of King Farouk, 347/ Barrie St. Clair McBride, Farouk of Egypt, 218. / Hugh McLeave, The Last Pharaoh: Farouk of Egypt, 288-289

${ }^{115}$ Latifa M. Salim, Farouk min al- milad ela al-rahil, 835

${ }^{116}$ Message from Ex-King Farouk, September 21, 1956, 4P, Security Declassified. Eisenhower Library, papers as president of the United States 1953- 1961, White House, confidential, 2-3

${ }^{117}$ Ex-King Farouk's Letter to the President, September 27, 1956, 4P, Security Declassified. Eisenhower Library, papers as president of the United States 1953- 1961, White House, confidential, 1.

${ }^{118}$ The US Department of State, a Letter From Mahmoud Abu al Fath to Department of State, 9.

${ }^{119}$ The US Department of State, a Letter From Mahmoud Abu al Fath to Department of State, 1-2-3.

${ }^{120}$ The US Department of State, a Letter From Mahmoud Abu al Fath to Department of State 3-4.

${ }^{121}$ The US Department of State, a Letter From Mahmoud Abu al Fath to Department of State, 6.

122 The US Department of State, a Letter From Mahmoud Abu al Fath to Department of State 8.

${ }^{123}$ The US Department of State, a Letter From Mahmoud Abu al Fath to Department of State, 9.

Mahmoud Abu al Fath passed away in August 1958 in Geneva, then he moved upon his will to Tunisia to be buried there in August 20, 1958.

The Egyptian National Archive, the Archive of the Ministry of Foreign Affairs, Microfilm 58, Folder 118, Archival Code 034557-0078 